\title{
O Uso Musical do Silêncio
}

\author{
Marco Antonio da Silva Ramos
}

A ausência da manifestação sonora, a ausência de manifestação de todos os parâmetros do som, caracteriza o que chamamos de silêncio. Na música, o silêncio tem notação própria e ocupa espaços perfeitamente delimitados no tempo.

Analisando a utilização do silêncio na música, o que estamos observando é como ele se manifesta enquanto fenômeno sonoro: como a ausência que justifica a presença, como a ausência que penetra e constrói, junto com a presença, um discurso musical.

A utilização do silêncio na construção do discurso musical possui uma importância construtiva. Musicalmente, não existem variáveis no silêncio além de sua duração' ${ }^{1}$. No entanto, não são apenas as variações paramétricas dos sons que produzem música. É necessário que estes sons se articulem, se organizem; é necessário que, nesse processo, cada som responda a uma ou diversas funções dentro de algum tipo de discurso musical.

A ausência do som na música, o silêncio, representado pela pausa, possui no discurso musical uma possibilidade de articulação tão presente e com funções tão múltiplas quanto o som. Como proposição artística, o discurso musical desenvolve-se sempre em pelo menos dois níveis diferentes mas simultâneos: um discurso afetivo, expressivo, eum discurso estrutural. Uma das características que podem ser destacadas no processo analítico da música é precisamente a da simultaneidade enquanto projeto construtivo intrínseco. 
Neste artigo, analisaremos separadamente o que passaremos a chamar de Uso estrutural do silêncio e Uso gestual do silêncio, referindo-nos exatamente aos dois níveis de discurso citados. Entre estes dois itens incluímos um terceiro, a título de subsídio, tratando do Uso musical do gesto, indispensável para que nossa proposição do uso gestual do silêncio possa ser compreendida. Dispensamos um item semelhante com relação às questões estruturais, por se tratar de matéria bastante desenvolvida na literatura musical, e para a qual indicamos as obras listadas na bibliografia.

\section{O Uso Estrutural do Silêncio}

Pode ser considerado como estrutural aquele dado musical que esteja ligado de maneira intrínseca à realização do discurso enquanto projeto construtivo. Tanto mais estrutural um dado musical será (no caso, o silêncio) quanto mais indispensável e mais capaz de condicionar o pensamento composicional ele for. Convém lembrar que a principal função da divisão entre usos estruturais e gestuais é didática, uma vez que a mecânica dos usos do silêncio e suas relações com o texto literário ou musical fazem com que grande parte das aparições tenham um uso misto, cumprindo tanto funções estruturais como gestuais. Em determinadas circunstâncias, um silêncio gestual poderá se confundir com um estrutural ou mesmo converter-se numa parte tão indispensável à realização do discurso, que nos fará classificá-lo como estrutural.

As supressões de partes do conjunto utilizado na composição, neste artigo, serão consideradas como aparições parciais do silêncio. Observando uma obra polifônica, podemos perceber que, freqüentemente, uma ou mais vozes se calam enquanto outras permanecem: silêncio parcial.

Os procedimentos de instauração do silêncio podem ocorrer:

a) por corte: quando todo o conjunto empregado se cala simultaneamente. (Exemplo 1 - comp. 19 e 20). 
Exemplo 1 - Ludwig van Beethoven $-5^{\text {a }}$ Sinfonia, Do menor, op. 67, I movimento - Ed. Eulenburg nำ 402.
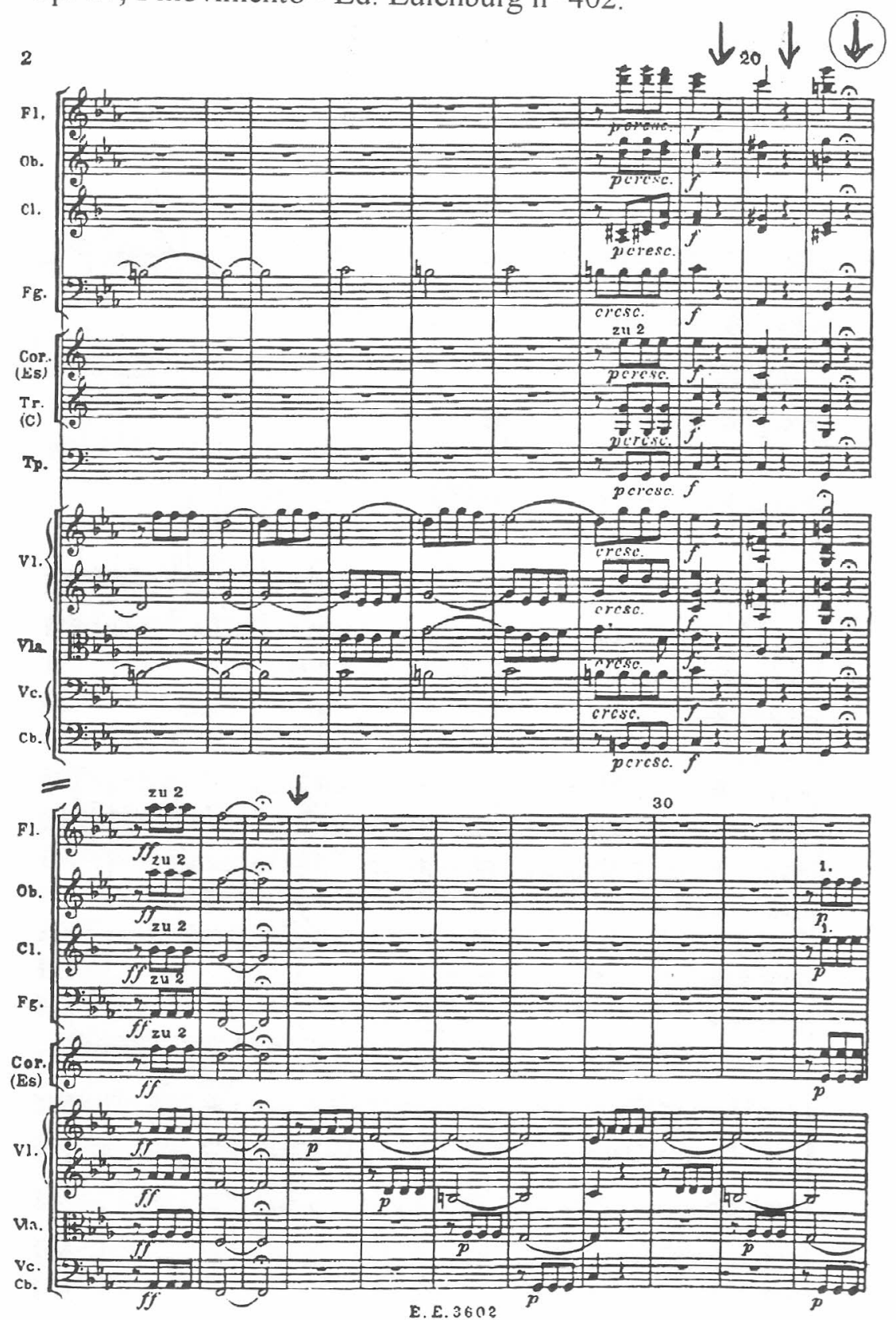

continua:

b) por filtragem: quando parte do conjunto se cala e parte (Exemplo 1 - comp. 21)

Exemplo 2 - Igor Stravinsky - "A Sagração da Primavera" Kalmus Orchestra Scores nำ78.

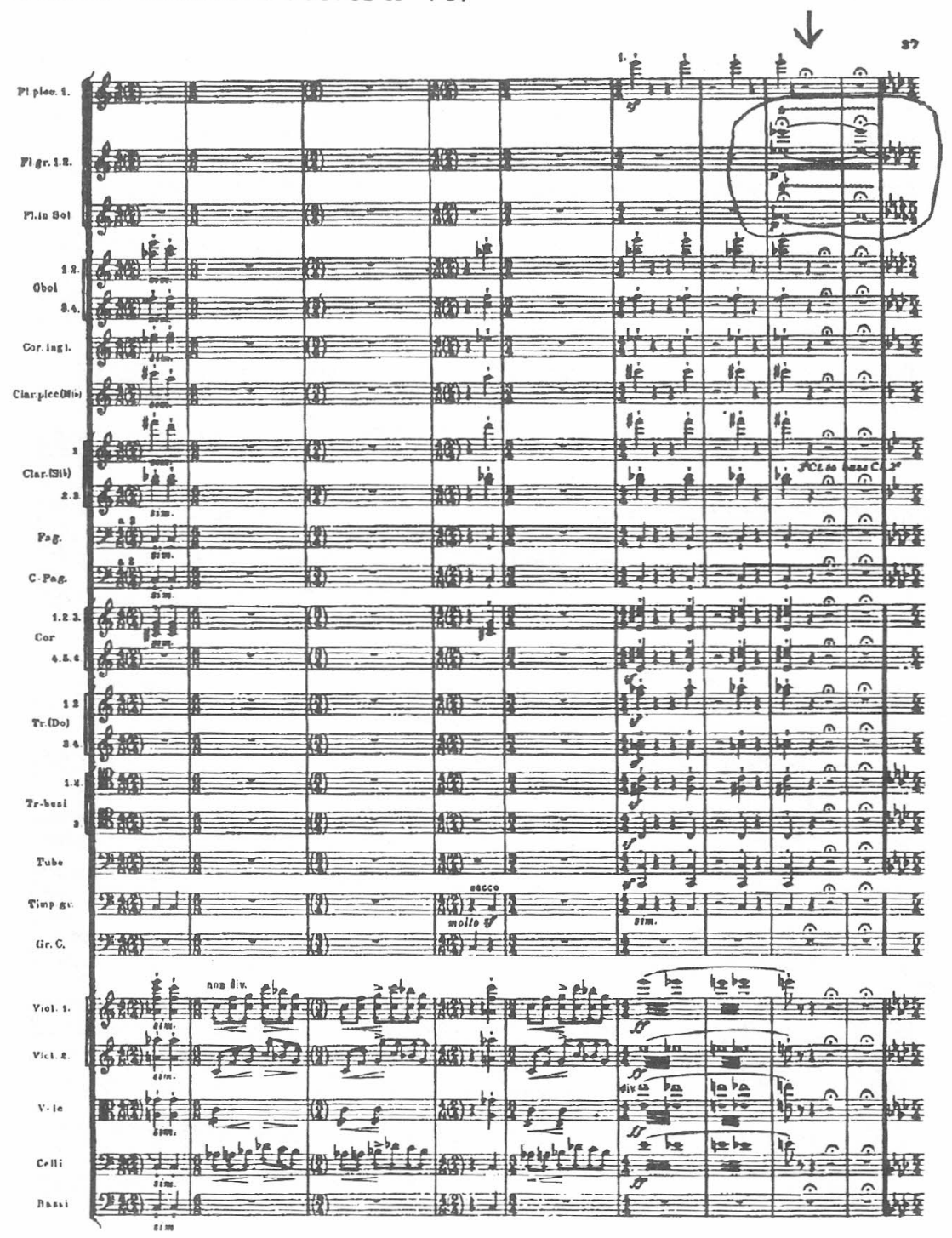


Tal processo pode evoluir paulatinamente.

c) por tendência dinâmica, quando em um decrescendo se estabelece uma tendência dinâmica al niente. Como em Cantique de Jean Racine, de Gabriel Fauré, onde, a partir do pp subito do compasso 71, há uma intercalação de grandes silêncios para o coro e uma tendência para $p p p$ além de uma tendência al niente no último compasso do piano.

Analogamente, classificamos o desaparecimento dos silêncios:

a) por corte, quando uma grande massa do conjunto empregado na composição ataca ao mesmo tempo.

(Ver exemplo 3).

b) por adição, quando os participantes do conjunto vão atacando suas notas um após o outro, paulatinamente.

(Exemplo 1 - comp. 25 a 28)

c) por tendência dinâmica, quando em um crescendo se estabelece uma tendência dinâmica dal niente. $\mathrm{O}$ Bolero de Maurice Ravel exemplifica esta tendência de maneira clássica.

Até aqui examinamos portanto apenas os modos de aparecimento e desaparecimento do silêncio. Isto é, como o silêncio se instaura e como o som se instaura quando precedido de silêncio. Estes modos têm, no decorrer do discurso musical, diferentes funções e subfunções, assim divididas:

1) Funções de articulação do discurso: a) função interruptora; b) função preparatória; c) funções de transição e/ou transformação.

2) Funções construtivas: a) temporal; b) estrutural; c) polifônica; d) timbrística.

3) Funções técnicas: a) instrumental; b) perceptiva.

\subsection{Funções de articulação do discurso}

Entendemos por articulação os processos de ligação entre as partes, subpartes, micropartes do discurso. Tais funções se manifestam concretamente das maneiras abaixo descritas: 
Exemplo 3 - Ludwig van Beethoven - $9^{\mathrm{a}}$ Sinfonia, Ré menor, op. 67, III para IV movimentos. Ed. Eulenburg no 411 .

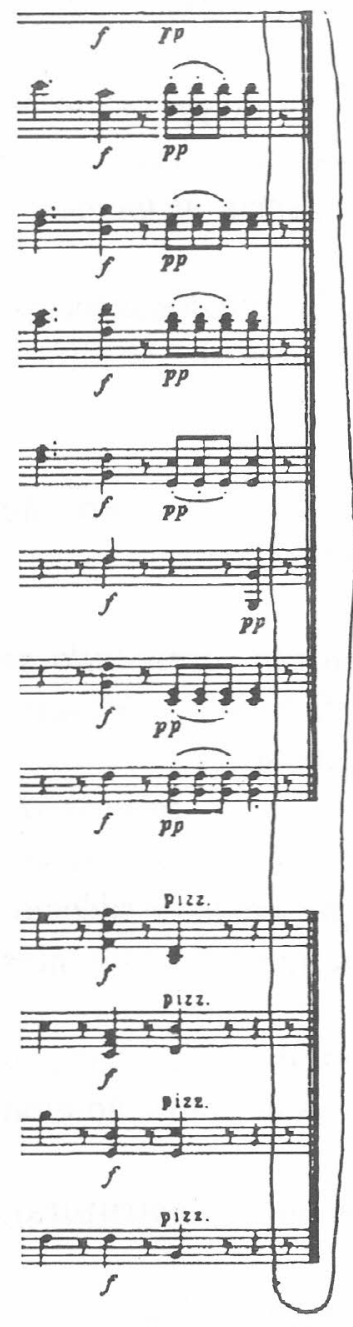

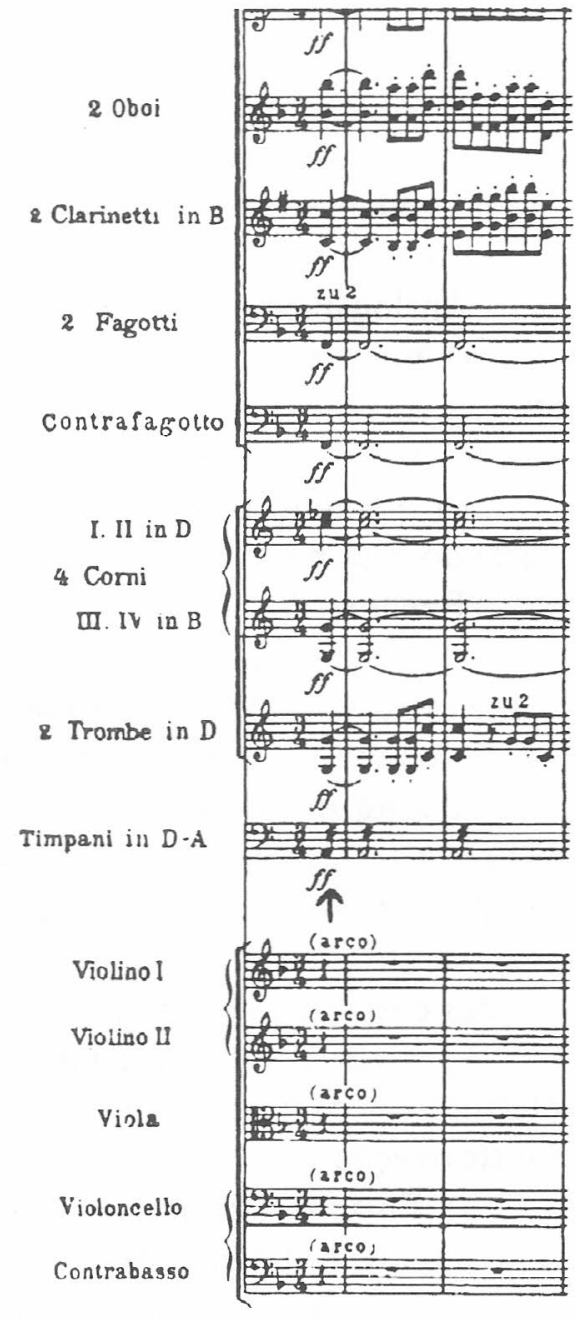

E.I. 3618

a) Função interruptora - aquela que faz cessar o discurso. Faz-se presente no final de uma obra:

(Ver exemplo 4).

No final de cada uma de um conjunto de peças, como as Liebeslieder Walzer op. 52 de J. Brahms; no final de partes de 
Exemplo 4 - Igor Stravinsky - "A Sagração da Primavera" Kalmus Orchestra Scores nำ 78.

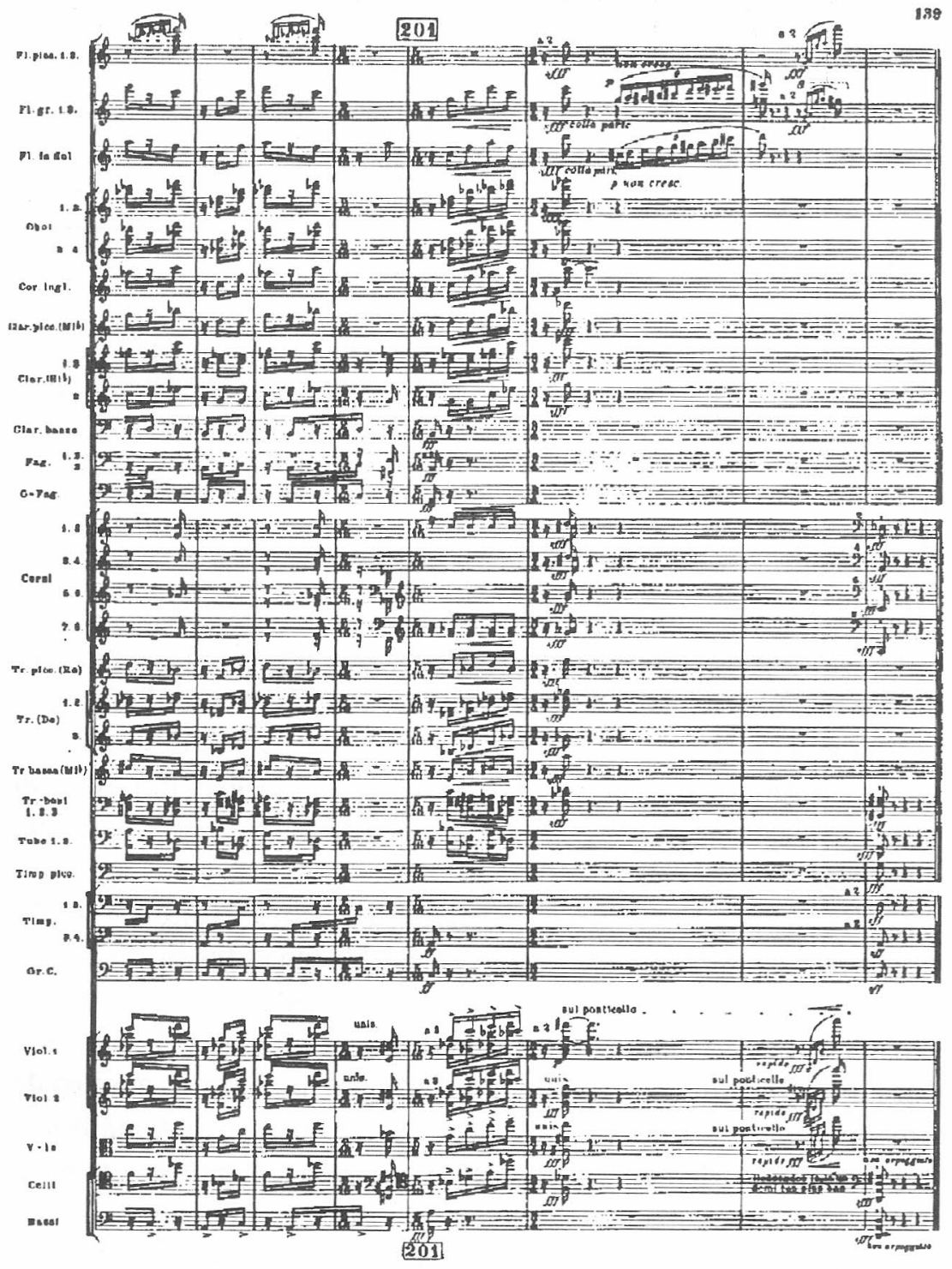

grandes obras, como missas, oratórios, sinfonias, sonatas etc. (Ex. 3); ou ainda interrompendo um fluxo de informações que, após o silêncio, não passa por transformações importantes, apenas continua, prossegue. (Ex. 5). 
Exemplo 5 - Marco Antonio da Silva Ramos - Intermezzo II, para Cicerros (Cow-Bells) das "Tres Historietas del Vento". S.Paulo, Editada pelo Museu Lasar Segall, 1981.
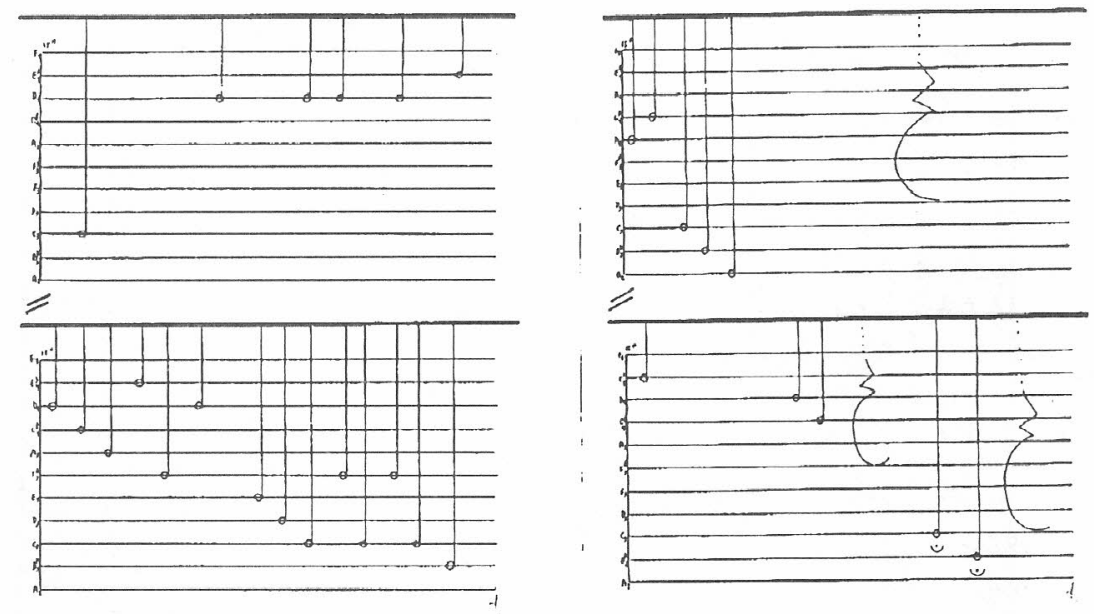

b) Função preparatória - pode ser pensada como o fato contrário à função interruptora. Dentro de um discurso musical, ocorre quando a idéia anterior passou por um processo de liqüidação até ser abandonada ${ }^{2}$. Um silêncio após uma liqüidação deste tipo assume a função de uma preparação para o que está por vir. Um exemplo deste procedimento pode ser visto em $\mathrm{F}$. Chopin, em sua 4.a Ballade. (Ver exemplo 6) .

É possível, também, considerar como tendo função preparatória aquele silêncio que se estabelece antes de se iniciar uma execução, o silêncio que permite ao ouvinte e aos intérpretes uma preparação para a música que será executada. É bastante comum que, numa obra de fôlego, entre um movimento e outro de um concerto o público se mexa na cadeira, tussa, balbucie impressões ao vizinho. Mas quando o maestro demonstra que vai iniciar novo movimento, o silêncio se instala novamente.

c) Funções de transição elou de transformação. Para se estabelecer uma transição é necessário que existam fatos musicais distintos, para que se possa abandonar um e introduzir outro. $\mathrm{O}$ silêncio, neste caso, terá em suas duas margens fatos musicais 
Exemplo 6 - Frédéric Chopin - Balada op. 52 n 4 - Polskie Widawnictwo Muziczne nำ232. Paderewski, editor.
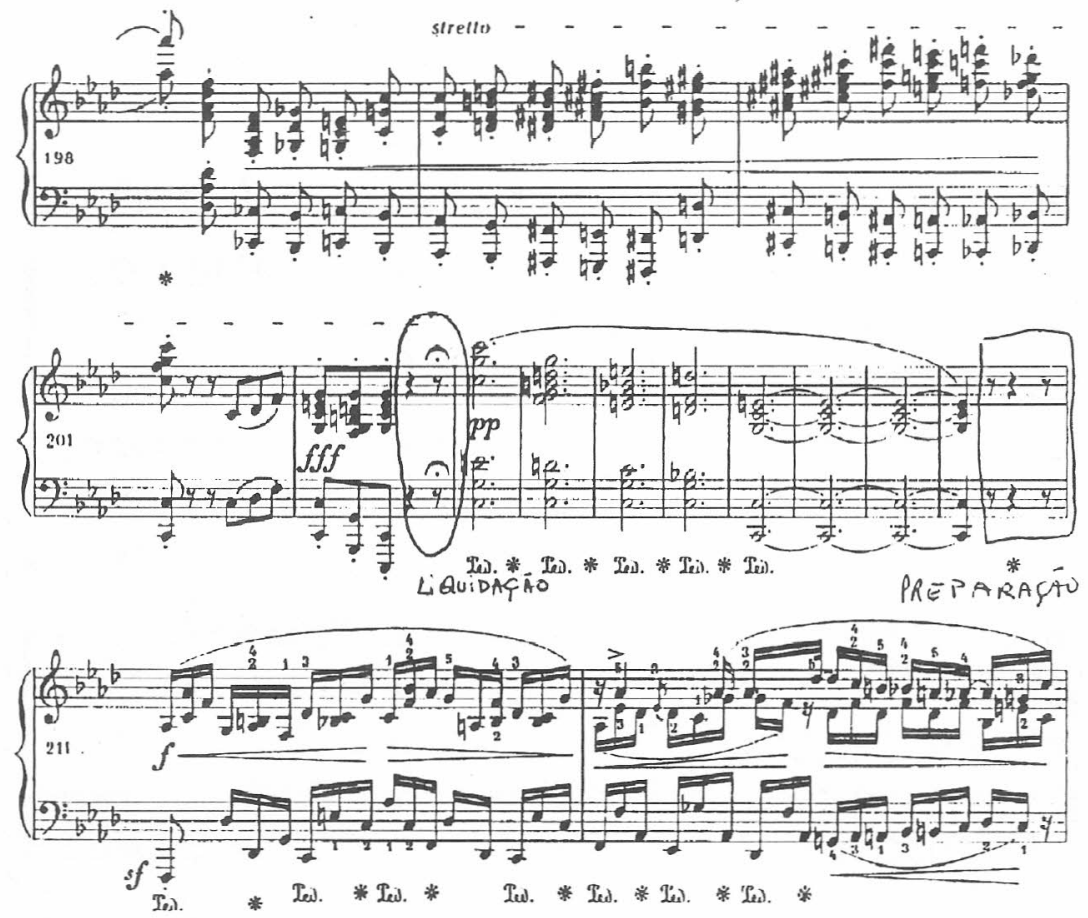

diferentes. Assim pensando, podemos vislumbrar alguns tipos de funções de transição e/ou transformação:

- No campo da harmonia, se, em cada margem, estivermos em uma tonalidade diferente e definida, o silêncio terá uma função de MODULAÇÃO.

(Ver exemplo 7).

- No âmbito do discurso propriamente dito, entre partes, subpartes ou micropartes, a presença do silêncio poderá desempenhar a função de unir estas partes, quando terá uma função de PONTE

(Ver exemplo 8),

ou poderá ter uma função de desunir estas partes, quando terá uma função de SEPARAÇÃO.

(Ver exemplo 9). 
Exemplo 7 - Joseph Haydn - Sinfonia em Sol - "Militar" Hoboken I: 100 München, G. Henle Verlag, 1966.

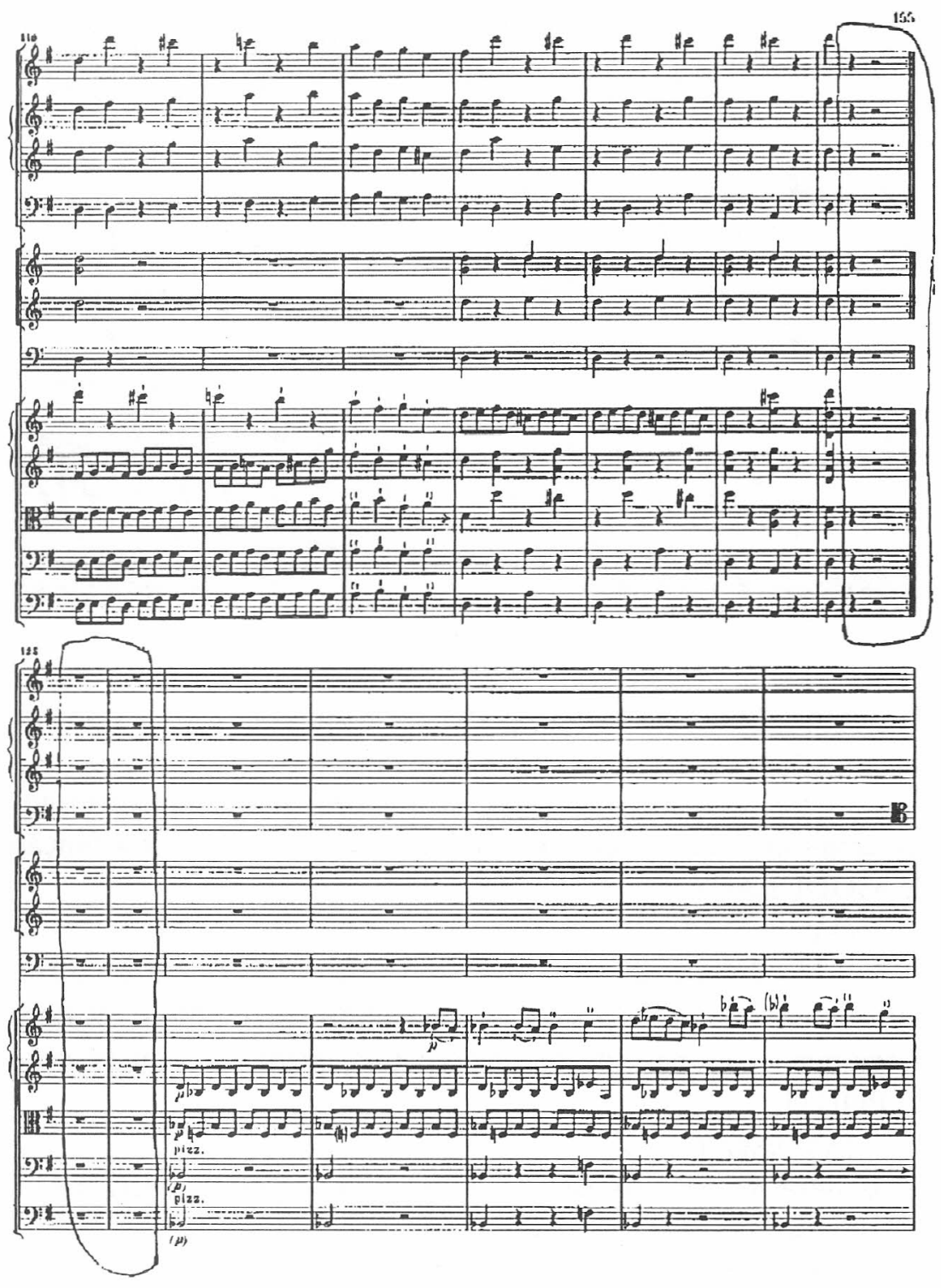


Exemplo 8-Ludwig van Beethoven - Quarteto op. 135, em Fá Maior - Kalmus Study Scores $n^{\circ} 762$.

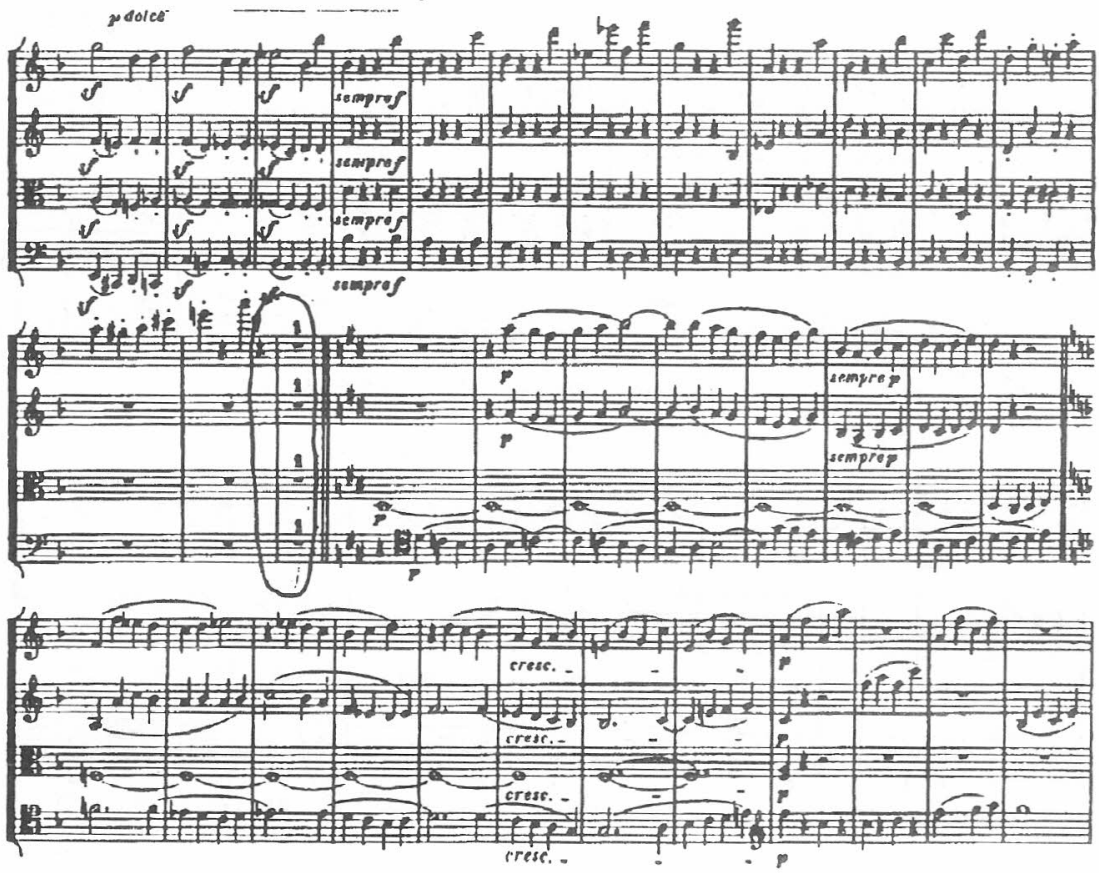

A definição entre essas possibilidades de PONTE ou SEPARAÇÃO é dada pela intensidade de atração ou repulsa entre as margens, assim como o quanto cada margem se fecha sobre si mesma. Partes de uma sinfonia costumam ter um sentido de integridade que faz dos silêncios que a separam quase um fato nãomusical, transformando tais silêncios em momentos de uma certa descontração. A expectativa se dá, então, por outra seção íntegra, mais do que por uma continuidade do discurso.

\subsection{Funções construtivas}

Chamamos de funções construtivas aquelas que, uma vez empregadas, fazem parte, de maneira indissociável, do pensamento musical ao nível da estrutura, dos procedimentos composicionais e de instrumentação. 
Exemplo 9 - Franz Liszt - "Christus ist geboren" - Kalmus study scores $n^{\circ} 9387$.

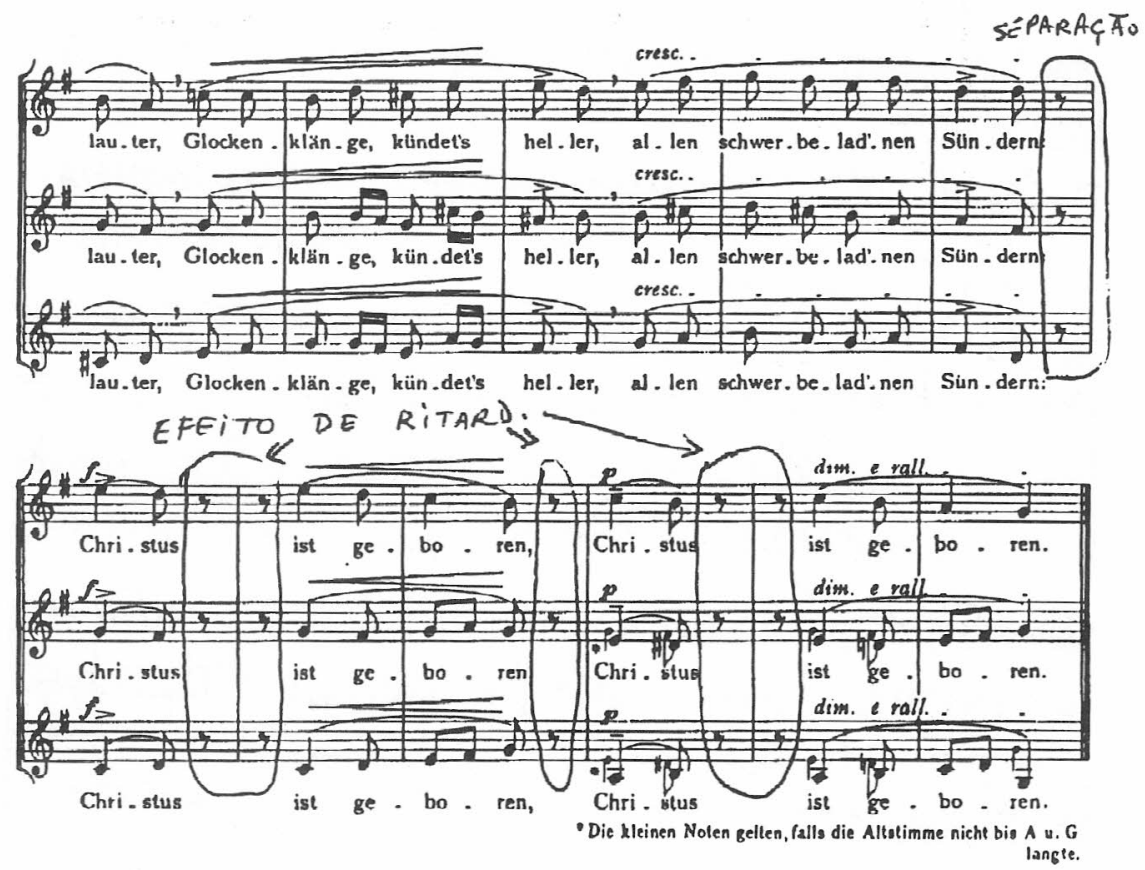

Observando a natureza desses silêncios, nós os separamos nas seguintes categorias:

a) de natureza TEMPORAL. Silêncios têm, como já vimos, um único parâmetro: o do tempo. Nesse sentido, nós os separamos em ritmicos e de andamento.

- RÍTMICOS são aqueles que viabilizam, no contraste com o som, a formação de certos ritmos ou mesmo viabilizam a formação de determinados motivos.

Exemplo 10 - Béla Bartok - "Mikrokosmos" vol. VI, n 151 - Boosey and Hawkes music pub. Ltd., H15187.

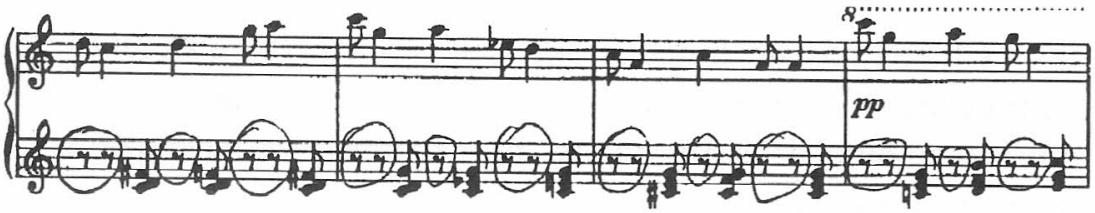


Exemplo 11 - Ludwig van Beethoven $-5^{\mathrm{a}}$ Sinfonia, Dó menor, op. 67, I movimento - Ed. Eulenburg nำ 402.

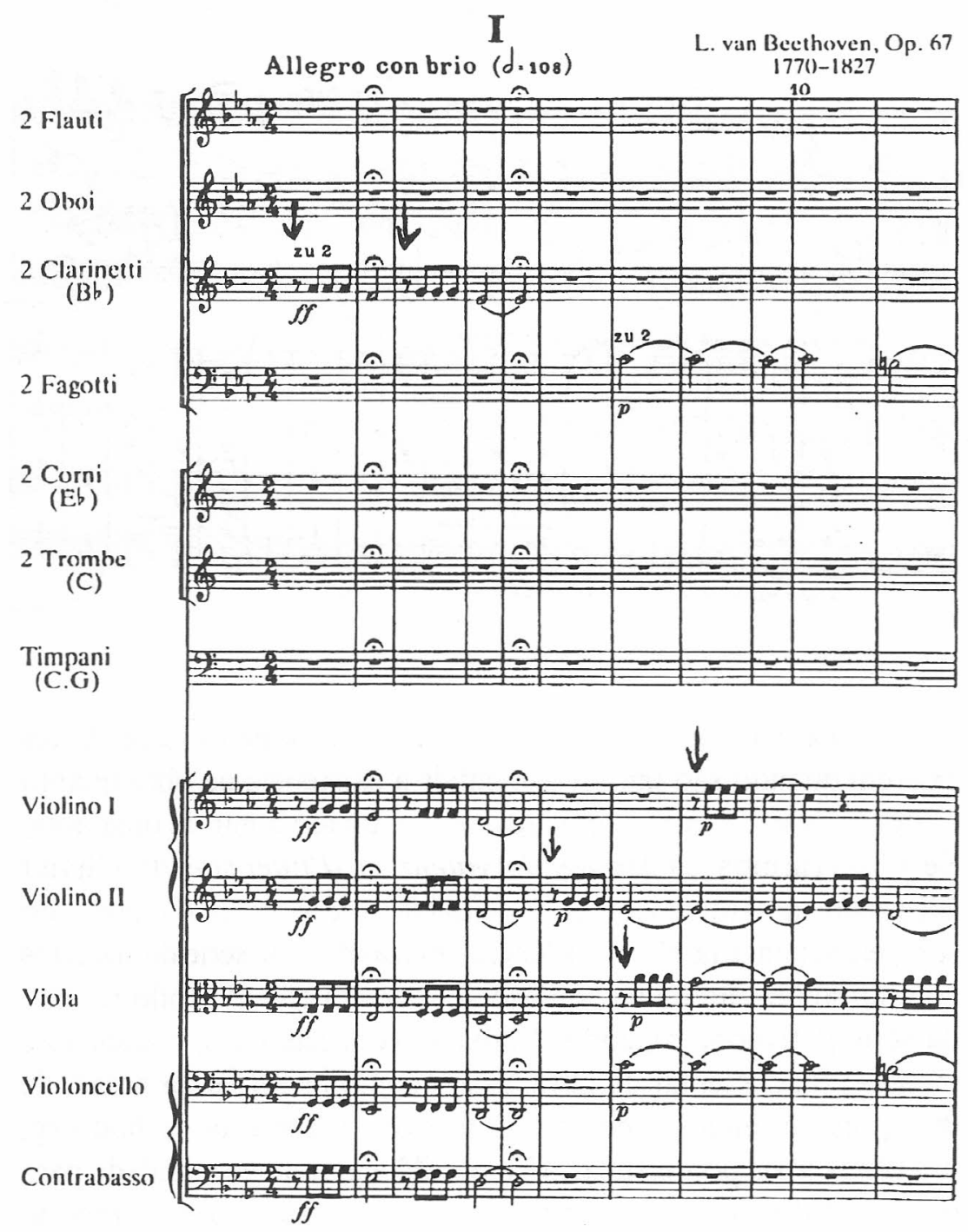


- DE ANDAMENTO são aqueles que provocam ou são usados para provocar alterações no andamento de determinado trecho, seja acellerando ou ritardando. (Ver exemplo 9).

Exemplo 12 - Ludwig van Beethovem - Quarteto op. 133, em Si b Maior - Grande Fuga - Kalmus Study Scores nํㅜ․ 762 .

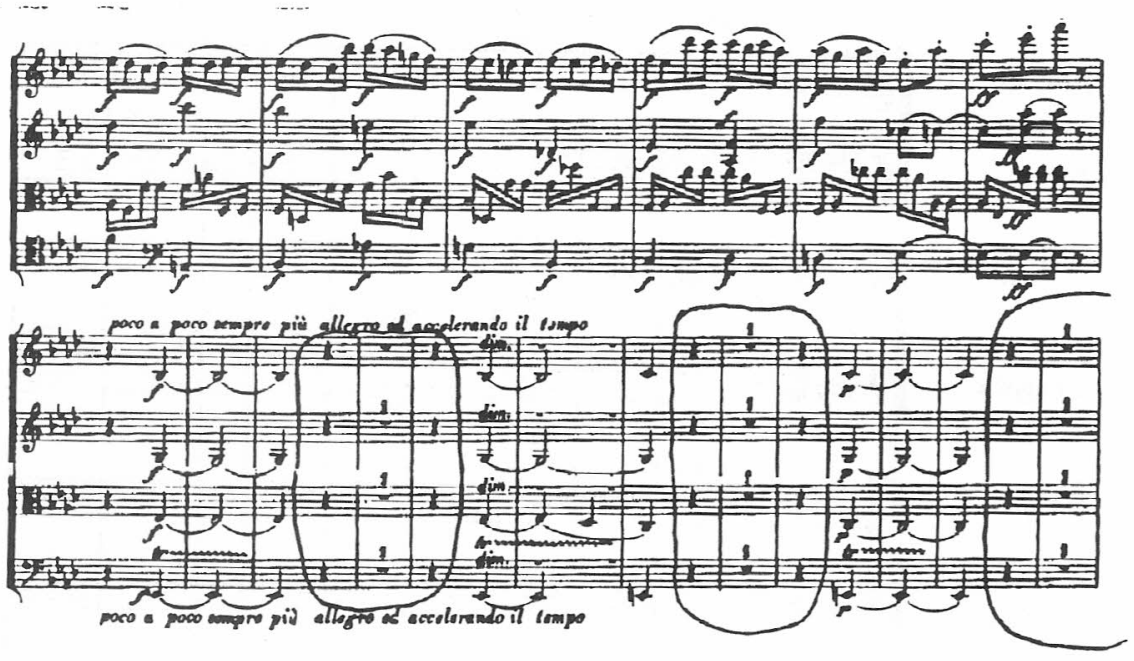

b) de natureza ESTRUTURAL propriamente dita. Estes existem quando são tão fundamentais à existência da obra quanto o próprio som. É como se ocupassem o devido lugar de uma nota. Se observarmos os Modes de valeur et d'intensité de Olivier Messiaen, notaremos que, ao serializar todos os parâmetros do som, ele serializa também o silêncio, utilizando uma série de silêncios com durações diferentes, que só se repetem quando todo o resto da série já tiver se repetido. Como se vê, neste caso, o silêncio é material fundamental da obra, assim como as séries de notas, de durações, de intensidades ou de timbres. Webern ou Schönberg, nas obras mais pontilísticas, têm no silêncio uma necessidade para que os pontos se erijam como pontos. Sem o silêncio em torno, no mínimo, se tornariam blocos. 
Exemplo 13 - Anton Webern - 5 peças para Orquestra op. 10 Universal/Philarmonia $\mathrm{n}^{\circ} 449$.

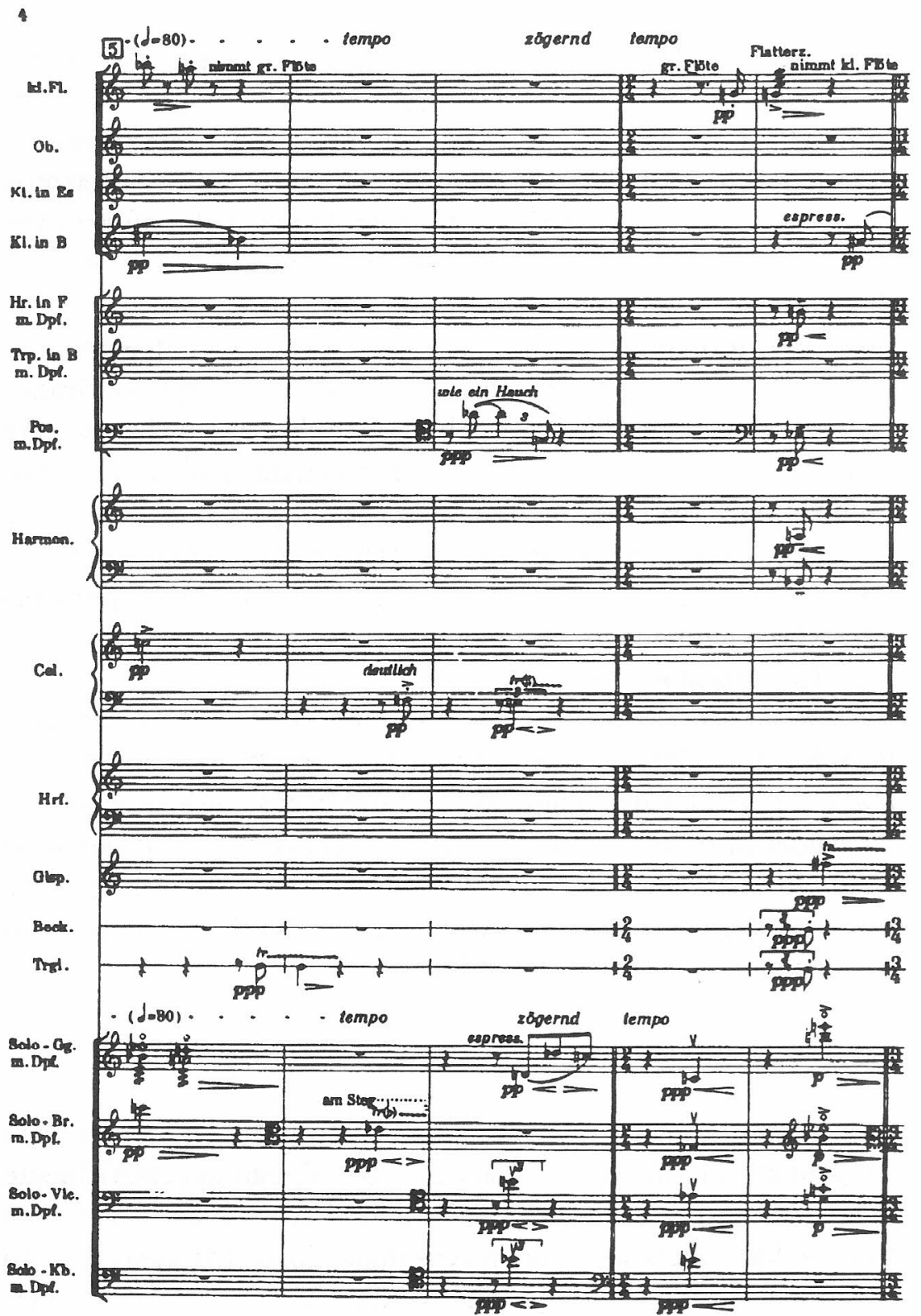


c) de natureza POLIFônICA. Aqui se trata principalmente do que anteriormente descrevemos como silêncio parcial. Não se pode falar, é claro, em polifonia de silêncios. A idéia é de que o silêncio de certas vozes, em determinados momentos, permite que a textura polifônica se realize de forma variada e, com efeito, freqüentemente viabiliza a polifonia enquanto procedimento. Se observarmos - Madrigal Ad un dolce usignolo de Adriano Banchieri (Ver exemplo 14), notaremos a grande desenvoltura no tratamento das vozes ou grupos de vozes ambientadas pelo silêncio das outras. Algumas vezes, nesses casos, a relação entre silêncio e matéria sonora lembra o recurso plástico de figura e fundo.

d) de natureza TIMBRÍSTICA. Grande é a semelhança entre este uso do silêncio e aquele que chamamos de polifônico. Freqüentemente podem confundir-se. Mas aqui, o que diferencia é o objetivo sonoro a que se visa. Quando silencia um instrumento ou um grupo de instrumentos de um tutti de orquestra, a principal alteração é nitidamente no timbre.

(Ver exemplo 15).

Assim também na voz, se um grupo de vozes graves é introduzido, calando as vozes agudas, o resultado timbrístico se altera, em virtude da quantidade de harmônicos que aparecerão ou da mudança de tessitura. A obra de Garcimuñoz, Una montaña pasando, está cheia de exemplos desta espécie de orquestração vocal concretizada pelos silêncios. Aqui, como no item anterior, o silêncio age como um viabilizador.

\subsection{Funções técnicas}

Entendemos por técnicas as funções que, embora freqüentemente limitem o discurso musical, não necessariamente aparecem na partitura em função dele. Elas aparecem por uma necessidade técnica, uma necessidade do instrumento ou do instrumentista ou da percepção do ouvinte. Em vista disso, elas podem ser divididas em: 
Exemplo 14 - Adriano Banchieri - "Madrigale ad un Dolce Usignolo" - in: "Collana di composizione sacre e profane". Vol. III. Milano, Ed. Curci - Achile Schinelli, editor.
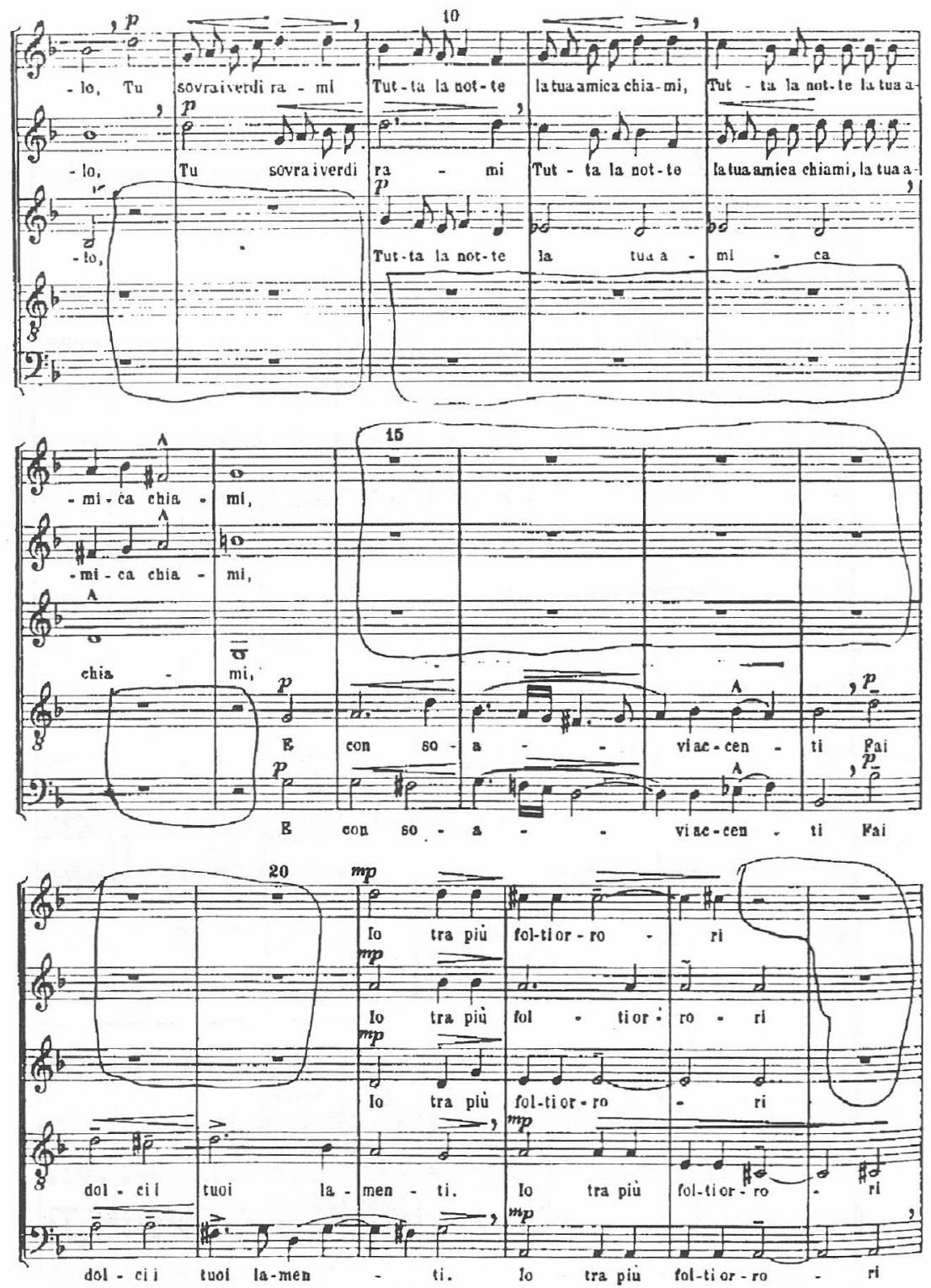

E. 652 C. 
146 Revista Música, São Paulo, v. 8, n. 1/2: 129-168 maio/nov. 1997

Exemplo 15 - Igor Stravinsky - "A Sagração da Primavera" - Kalmus Orchestra Scores nº 78.

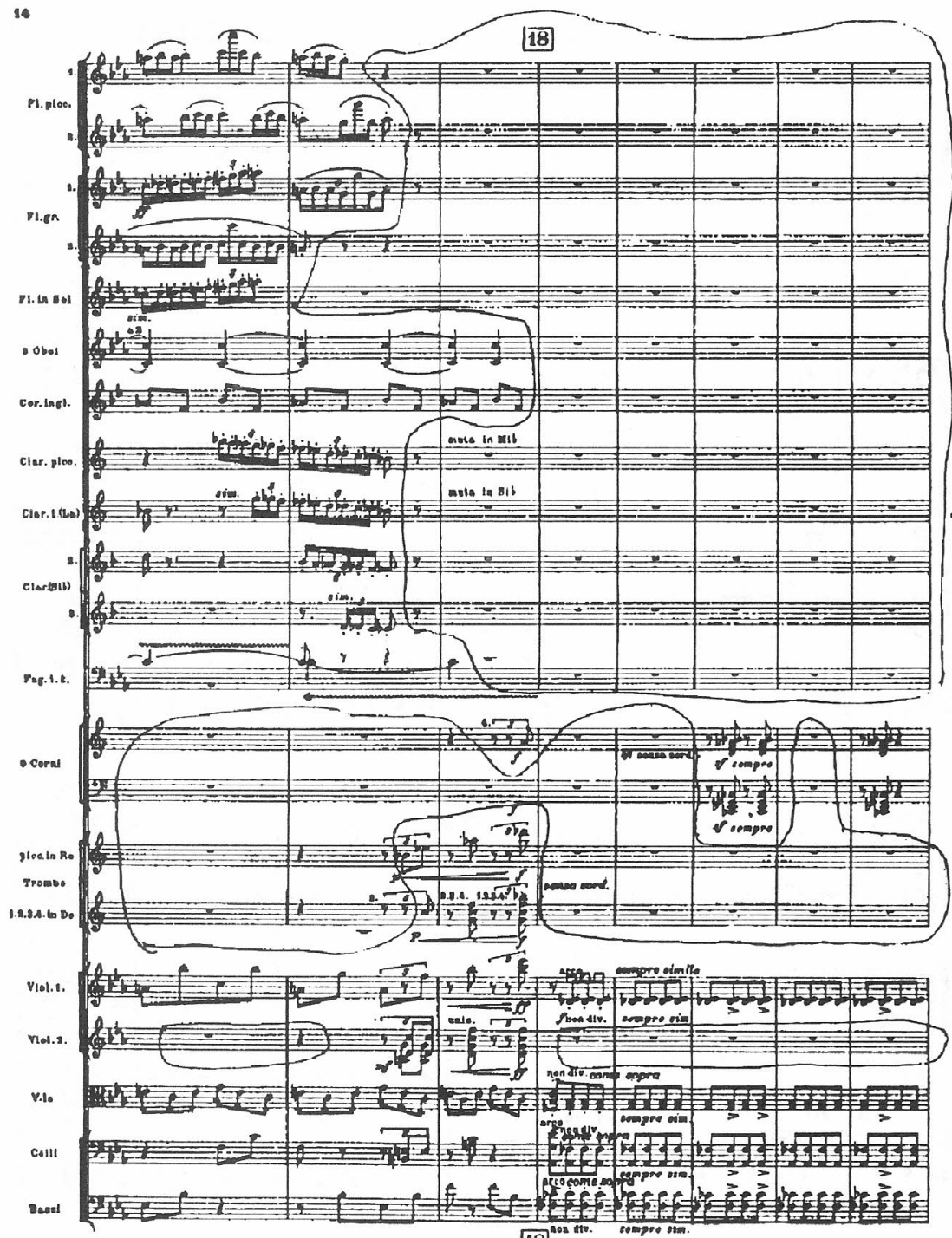


a) de natureza INSTRUMENTAL - quando o instrumento exige o aparecimento de um silêncio para que o próximo som possa ser emitido. Como exemplo, citamos as situações em que o fôlego do cantor ou soprista exige nova respiração; as situações em que um percussionista deve mudar de instrumento ou de baquetas, afinar os tímpanos e outras situações semelhantes.

b) de natureza PERCEPTIVA - quando, em função da ressonância da sala em que determinada obra deva ser executada, é necessário dar uma duração maior aos silêncios (pausas) para que o excesso de reverberação não confunda o entendimento da obra (Ex. grandes igrejas) ou dar ao silêncio uma duração menor para que a excessiva falta de reverberação não retire à música a fluência que deve ter (Ex. salas de convenções acarpetadas de cima a baixo).

Certas obras já são construídas tendo em vista o espaço provável de apresentação. Quem nunca se perdeu, mergulhado na ressonância de um grande tutti num órgão de tubos de uma grande igreja?

Exemplo 16 - J. S. Bach - Tocata e fuga em ré menor BWV 565 - Schott Freres ํํ 8992.

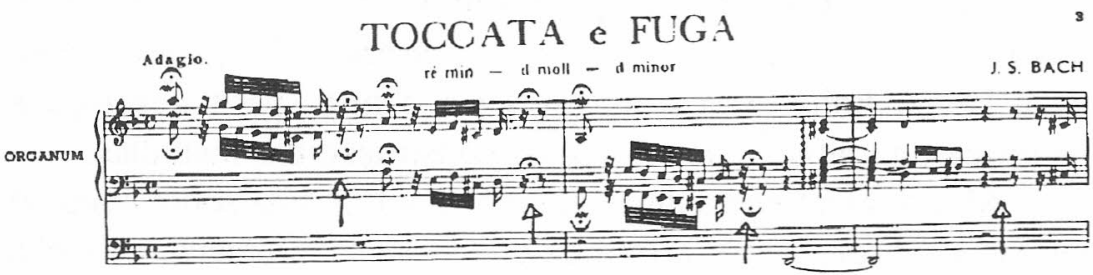

\section{O Uso Musical do Gesto}

É comum que o músico, mergulhado em seu fazer, observe em sua arte apenas os fatos e fenômenos que ocorrem no âmbito exclusivo do discurso musical; que observe e estude suas macro e microformas, seus modos de ação e construção, sua estrutura, a articulação dos parâmetros sonoros em discurso musical, as leis diretoras do edifício harmônico ou contrapontístico, as partes da melodia etc. 
Existem, porém, momentos em que o discurso musical se constrói a partir de ou sobre uma referência exterior a ele mesmo. É neste momento que se configura o que chamamos GESTO MUSICAL. O momento em que a música aborda e assume discursos externos a ela, qualquer que seja este exterior. Assim, é possível encontrar em toda a história da música exemplos de abordagens miméticas (onomatopaicas), de abordagens que aproximam o discurso melódico do discurso verbal, abordagens que sublinham ou integram discursos dramáticos, abordagens que comentam ou homenageiam outras obras já escritas e conhecidas (e que, portanto, transformam estas próprias em referenciais externos ao discurso que se constrói sobre elas).

Quando Monteverdi, em seu madrigal $A$ un giro sol de 'bell'occhi lucenti, ao texto certo quando nasceste cosi crudel e ria (do $4^{\circ}$ Livro de Madrigais) justapõe uma sucessão de dissonâncias bastante duras nos tempos fortes, que se amenizam nos tempos fracos gerando novas dissonâncias nos tempos fortes e assim sucessivamente, ele está intencionalmente sublinhando a crueldade a que o texto se refere, ao mesmo tempo em que usa um código comum aos madrigalistas anteriores ou contemporâneos a ele: para a dor, dissonâncias; para o amor e a felicidade, terças, se possível paralelas; para a morte, linhas direcionadas para o grave; para Deus, linhas direcionadas para o alto; para descrições pictóricas, a imitação de relevos na construção das melodias.

Muito da intenção descrita no exemplo acima sobreviveu no mundo da ópera, onde a música quase necessariamente sublinha uma ação dramática (recitativos) ou um certo sentimento, estado de espírito ou situação psicológica (ária). Pode-se reconhecer Átila e suas hostes e o Papa no poema sinfônico (música programática) A Batalha dos Hunos de Franz Liszt. Ou reconhecer franceses e russos na Abertura 1812 de Tchaikovsky.

Através dos exemplos citados, observa-se que o ato da composição, o ato intencional do criador pode se apoiar e interagir com estes subtextos, estes referenciais não estritamente musicais e pode assim fazer transparecer estas intenções dentro de seu 
próprio discurso musical. Assim, consideramos o uso do gesto na música: o momento musical que faz referências intencionais a um universo não-musical.

Quanto à problemática do silêncio, será também através dos múltiplos usos gestuais possíveis que analisaremos sua integração ao discurso musical, seja quando a música comenta a música, seja quando se refere diretamente a pensamentos, palavras, sons e atos não-musicais.

Os diferentes níveis de ocorrência do gesto musical podem ser agrupados em dois troncos principais: o gesto musical sobre referências musicais e não-musicais.

\section{Os Níveis do Gesto Musical}

\section{1 Oesto musical sobre referência musical}

Em toda a história da música ocidental é possível encontrar exemplos de obras que têm como objeto outras obras, as quais servem como um motivador, um objeto de homenagem, um objeto de crítica ou escárnio, um objeto de reminiscência. De qualquer maneira, o fato musical novo se dá em referência a algo externo a ele, fazendo um outro discurso sobre um discurso já feito e conhecido. Tomamos aqui um termo emprestado à lingüística, o de metalinguagem ${ }^{3}$. Voltando à história, observamos em Gustav Mahler, no Primeiro Movimento de sua Quinta Sinfonia, a alusão direta e constante ao tema da Quinta Sinfonia de Beethoven. Luciano

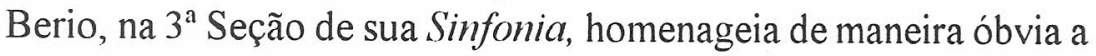
Segunda Sinfonia de Gustav Mahler, fazendo uso de seu Terceiro Movimento e, sobre ele, faz referências a Bach, Berg, Schönberg, Debussy, Ravel, Strauss, Berlioz, Brahms, Boulez, Stockhausen, Globokar, Pousseur e ao próprio Berio. Este conjunto de atitudes acima descrito pode ser chamado de gesto musical metalingüístico propriamente dito.

Existe um outro nível de metalinguagem enquanto gesto musical, que chamaremos gesto musical conceitual, ou seja, aquele em que o comentário se dá menos a obras específicas e mais a 
idéias musicais ou à própria música enquanto entidade. Assim, a obra de Eric Satie Três peças em forma de pera ironiza uma mentalidade de ensino de composição musical na Paris de então, comenta a questão da forma musical, satiriza a coda clássica. Mais radicalmente, John Cage nega à música sua própria condição de manipuladora dos sons ao pedir, na sua famosa obra de 1952, 4 mimutos e 33 segundos, que o intérprete permaneça à frente do piano pelo número de minutos e segundos que dão nome à obra sem tocar uma só nota. Eis que, descendente do Dadaísmo, esta obra de Cage, como algumas de Satie, só se coloca como obra porque o compositor, se valendo da situação de ser um compositor, diz de sua obra: ela é uma obra. A idéia é que, como na chamada Arte Conceitual, é possível desprezar eventualmente a própria artesania do compositor fazendo com que a obra seja apenas e tão somente um conceito.

\subsection{O gesto musical sobre referências não-musicais}

Aqui se encontram referências musicais aos domínios da literatura, do teatro, da imagem visual, da natureza, da psicologia. A cada um desses domínios a música se referirá, criando para si técnicas e procedimentos que enriquecem seu próprio domínio. Diante disto e principalmente diante do fato de que, afastando-se de seu próprio campo de ação, a música acaba por estabelecer relações cada vez mais subjetivas com estes domínios externos a ela, podemos desde já perceber que o campo do gesto é um campo onde os limites estão sempre um pouco mais à frente, um pouco mais definidos cada vez que se avança.

A tentativa de cercar certos procedimentos, de descrever certas referências servem para clarificar tais idéias, a partir de exemplos e análises. Didaticamente, podemos dividi-los em:

A) GESTOS MUSICAIS DESCRITIVOS

a - Gestos musicais descritivos de situações psicológicas;

b - Gestos musicais descritivos de situações visuais;

c - Gestos musicais miméticos. 


\section{B) GESTOS MUSICAIS DRAMÁTICOS E/OU NAR- RATIVOS}

a - Inflexionais;

b - Integrados à ação como narração de fatos e enredos;

c - Integrados à representação de um papel teatral.

\section{A) Gestos musicais descritivos}

Este subtítulo já define bem a característica fundamental deste campo do gesto musical. No entanto, o campo da descrição é vasto e é importante notar que, necessariamente, a descrição não se esgota em si mesmo. A intenção organizadora do compositor será sempre o que, fazendo uso deste gesto descritivo, transforma este material em obra ou em parte de uma obra. No Chant des Oiseaux de Clément Janequin, percebe-se uma alternância entre partes polifônicas puras e partes miméticas; observa-se também que o tratamento dado ao material constituído de imitações de cantos de diferentes pássaros obedece a critérios construtivos próprios, seja no âmbito do tratamento dos modos, seja na organização contrapontística, seja no tratamento das direcionalidades, das densidades, dos timbres etc. Ou seja: a obra não se esgota na descrição, ela a utiliza como gesto, como recurso. Tal pensamento pode e deve estender-se a toda música programática e a uma importantíssima parte daquilo que chamamos relação texto-música.

O campo dos Gestos Musicais Descritivos se subdividirá em tantas partes quantas os compositores (tomados como um todo) assim o desejarem. O campo sempre poderá se estender conforme se amplia, por exemplo, o limite do conhecimento humano. Por isso, as subdivisões propostas a seguir não pretendem nem poderiam pretender esgotar o assunto, mas apenas servir como guia e tentativa de encontrar entradas para uma atividade analítica. Assim sendo, sugerimos a seguinte subdivisão:

- Gestos musicais descritivos de situações psicológicas;

- Gestos musicais descritivos de situações visuais;

- Gestos musicais miméticos. 
Dado o fato de não ser objetivo deste artigo a descrição do amplo espectro de situações psicológicas, mas uma análise de seu uso musical, abordaremos apenas dois tópicos, porque pensamos serem eles os mais recorrentes: o das emoções e o das sensações.

\section{a) Gestos descritivos de situações psicológica}

Inúmeros são os depoimentos de compositores relacionando sua produção a emoções experimentadas. Um bonito exemplo é o de Claudio Monteverdi discorrendo sobre sua criação, o stilo concitato, quando afirma haver inventado uma forma para descrever a emoção guerreira, citando filósofos e observando que este sentimento ainda não havia sido explorado por outros compositores ${ }^{4}$.

Mendelssohn também nos fornece um bonito exemplo de descrição de emoções em sua canção para coro misto Auf dem see Op. $41 \mathrm{n}^{\circ}$ 6. Na parte B, há no texto de Goethe uma quebra do clima predominante na parte $\mathrm{A}$ : sonhos retornam à mente do poeta, retirando-o da atmosfera feliz e brilhante em que se encontrava. Expulsos os sonhos, o clima da parte A retorna. A música de Mendelssohn acompanha diretamente esta dinâmica em todos os seus parâmetros ${ }^{5}$. O contraste entre as partes $\mathrm{A}$ e B se dá a partir desta busca: fazer com que se oponham as emoções que cada uma destas partes procura descrever.

Mas, observando o madrigal Injourious Hours de Lichfild, podemos perceber outra ordem de Gestos Musicais Descritivos de Situações Psicológicas: os que dizem respeito a sensações, ainda que acoplados a emoções. "Horas injuriosas, que passam rapidamente quando as queremos lentas mas que quando as desejamos rápidas, se arrastam infinitamente como se nunca fossem terminar". Este é o sentido do texto musicado por Lichfild.

Na construção de sua obra, Lichfild faz com que a expressão "se arrastam" se repita de maneira imitativa, ocupando a maior parte do madrigal, através de antecipações e retardos encadeados, criando com isso um efeito de prolongamento do tempo que sublinha o sentido do texto. 
Outro interessante exemplo de gesto descritivo de sensação pode ser o clima geral de furtivo, de mistério, que grande parte das serenatas, dos noturnos, das canções sobre a noite procuram.

\section{b) Gestos musicais descritivos de situações visuais}

Estáticos ou cinéticos, da natureza ou da arte, o campo de gestos descrito neste caso é sempre plástico, é sempre visual.

O madrigal Ecco mormorcar l'onde aborda o texto descritivo/pictórico de Torquato Tasso, buscando juntar aos perfis e conformações do poema perfis e conformações musicais que de alguma forma os reproduza, injetando timbres claros e maior movimentação à chegada da aurora e da brisa matutina. Outros processos da mesma natureza se sucedem no decorrer do madrigal. E o mesmo Monteverdi apresenta, em $A$ un giro sol de 'bell'occhi hicenti, um exemplo de movimento e repouso no trecho e'l mar s'acqueta, onde e'l mar é cantado em melodias superpostas e homofônicas, que imitam o subir e o descer das ondas através de escalas ascendentes e descendentes. Ao texto s'acqueta todas as vozes cantam notas paradas. Assim, o perfil sonoro imita tanto o perfil plástico das ondas como o seu movimento.

(Ver exemplo 17)

\section{c) Gestos musicais miméticos}

Buscam aproximações com sons característicos de vida, seja na natureza ou em alguma ação do homem ou seus inventos. A idéia é utilizar este tipo de imitação trazendo o material assim obtido para uma organização de fato musical. Assim procedeu Clément Janequin, utilizando o som do canto dos pássaros (Le Chant des Oiseaux, Le Chant de l'Allonette), a voz humana (Les Cris de Paris, Le Caquet des Femmes) ou os ruídos da guerra (La Guerre ou La Bataille de Marignan). Antes dele, Adam de La Halle imitara o andar do cavalo (Or est Bayard), Josquin des Près, o canto do grilo (Il Grillo è Buon Cantore) e depois dele Monteverdi, a cavalgada e a batalha (Combattimento de Tancredi e Clorinda). 
Exemplo 17 - Claudio Monteverdi - "A un Giro Sol de" bell'occhi lucenti". In: IV livro de Madrigais. Universal Ed., F. Malipiero, editor, Opere di Monteverdi, tomo IV.
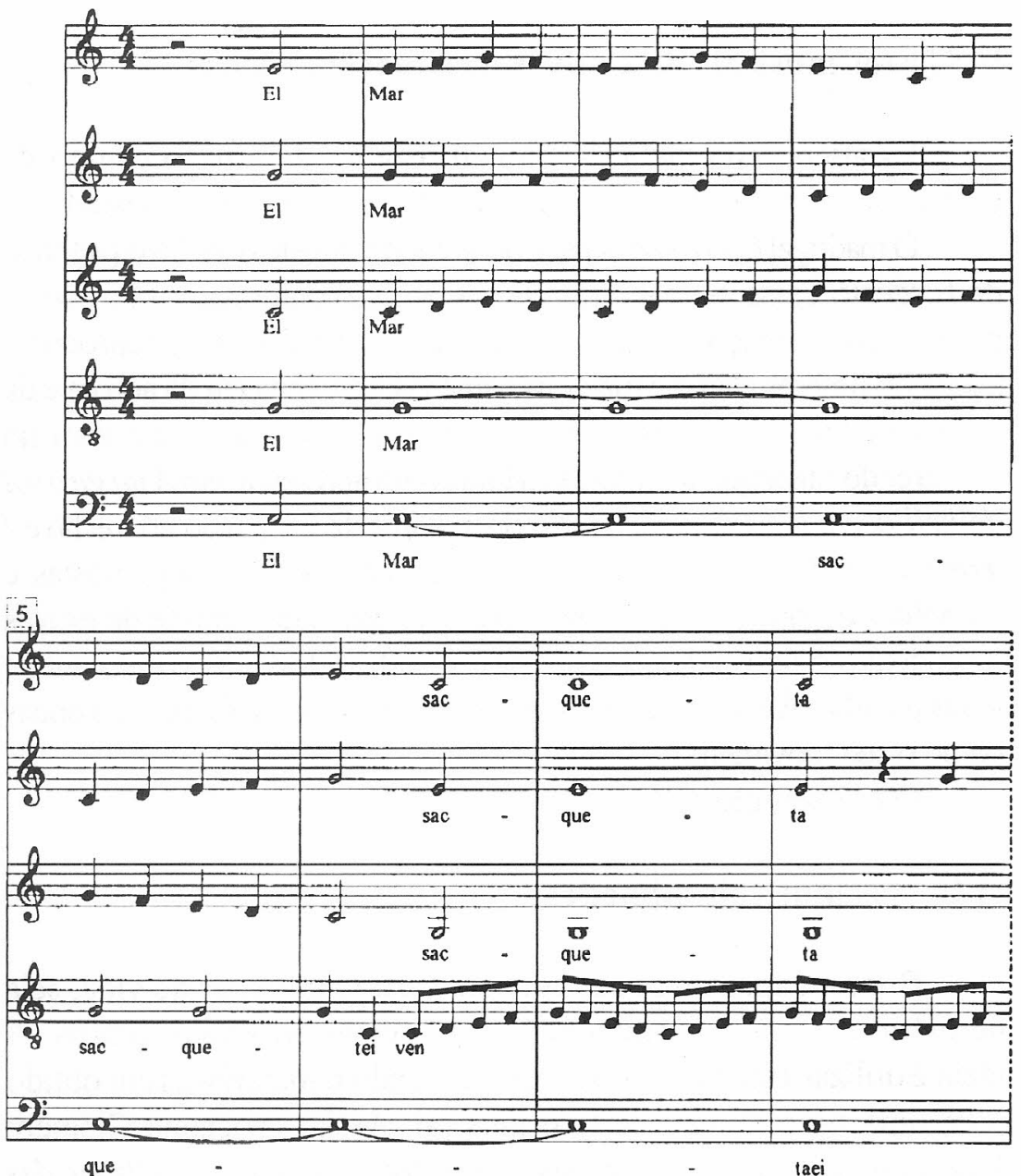

No século XX, Pierre Schaffer e outros empreendem a chamada Música Concreta, utilizando os recursos que a tecnologia de áudio pôs ao alcance do músico. A gravação de sons então chamados concretos (sons de rua, da natureza, do homem) e posteriormente organizados por processos de edição, embora muito mais próximos, obviamente, do resultado sonoro original do que 
podia Janequin se aproximar, é ainda assim uma mimesis. Mimesis eletrônica, uma vez que não é $a$ fonte que se faz presente, mas sim a sua reprodução eletromagnética.

Algumas vezes, o próprio processo de organização, transformação e manipulação intencionais deste material foi desprezado e o que se ouvia na sala de concerto era o resultado aleatório do somatório dos sons exteriores à sala, captados por microfones colocados em pontos diferentes da rua, da sala de espera, dos sanitários etc.

Os dois campos acima expostos podem se separar com uma certa nitidez, tendo como ponto de apoio argumentativo a intenção composicional. Quando o uso do material mimético ou reproduzido se dá dentro de uma organização composicional clara, fruto de um conjunto de intenções do compositor, estaremos no campo exclusivo da mimesis como gesto musical. Está claro, é um campo descritivo, o discurso pretende, de alguma forma, dizer algo sobre algo concreto, usando esta própria concretude para estruturar-se enquanto discurso. Portanto, são concretos tanto o material de uso da composição como o objeto do processo descritivo.

Outro campo se forma quando o material concreto é jogado dentro de uma sala de concerto sem qualquer ordenação, sem qualquer interferência do compositor. $\mathrm{O}$ resultado pode até ser "belo" ou "interessante", como pode sê-lo um pôr-de-sol ou uma orquídea. Mas a real intenção do artista ao ligar os microfones esparsos, trazendo aquilo que aleatoriamente eles puderem captar para dentro da sala de concerto, estará mais próximo do gesto conceitual do que do mimético, já que o resultado de sua ação só se torna arte porque ele, de sua condição de compositor, diz: isto é música, isto é arte e não apenas o ruído de um automóvel, um cão, um pássaro no parque, o barulho de uma torneira, um homem praguejando, ou o que seja. Nesse caso, o material, não tendo um pensamento composicional que o organize, é reprodução de fatos sonoros e não ultrapassaria o domínio da reportagem se não fosse o artista declarar seu status de arte. Aqui, portanto, o gesto é maior e a organização composicional é menor. Em virtude disto, para 
efeito do nosso trabalho, a expressão Gesto Musical Mimético estará se referindo somente ao primeiro campo exposto neste item, sendo que o segundo será lido no campo da metalinguagem, como um Gesto Musical Conceitual.

\section{B) Gestos musicais dramáticos e/ou narrativos}

Este campo traz consigo, já de início, uma questão polêmica: onde, aqui, fica o domínio literário, onde o domínio teatral? Como traçar esses limites? Estes podem ser colocados dentro de um mesmo campo, visto que, do ponto de vista do tratamento musical que se pode dar a cada um desses domínios, freqüentemente o que mais os diferencia talvez seja uma questão de ênfase. Ambos podem ser pensados como encadeamento de ações ou enredos, narrados ou representados, cantados ou musicados, explícitos ou freqüentemente sugeridos, agrupados como apresentados nos seguintes subitens:

a) Gesto musical inflexional - que se define pelo sentido de pontuação, de entonação, de expressividade que empresta ao discurso musical. Aponta interrogações, afirmações, exclamações. O que melhor o define é sua intenção de aproximação do discurso musical com a entonação do discurso falado. Certas respirações ou certas pausas podem funcionar perfeitamente como vírgulas ou como o tempo de pensamento de quem conversa, ainda quando não haja um texto:

(Ver exemplo 18).

Certas cadências afirmativas ou suspensivas, certos adiamentos no perfil melódico, certos descompassos rítmicos podem conferir ao discurso musical uma extrema proximidade com o discurso (narrativo, coloquial ou dramático) falado. Justapostos ao texto, tantos recitativos, em óperas, cantatas, tantos madrigais, tantas obras contemporâneas, tantas canções populares buscaram este caminho, que quase parece supérfluo apontarmos exemplos concretos. Mas vale lembrar o Recitativo da Rainha da Noite de Mozart; Moro Lasso, madrigal de Carlo Gesualdo di Venosa; 
Exemplo 18 - Frédéric Chopin - Noturno op. $37 n^{\circ} 1$. Polskie Widawnictwo Muziczne $n^{\circ} 238$, Paderewski, editor.

\section{DEUX NOCTURNES}
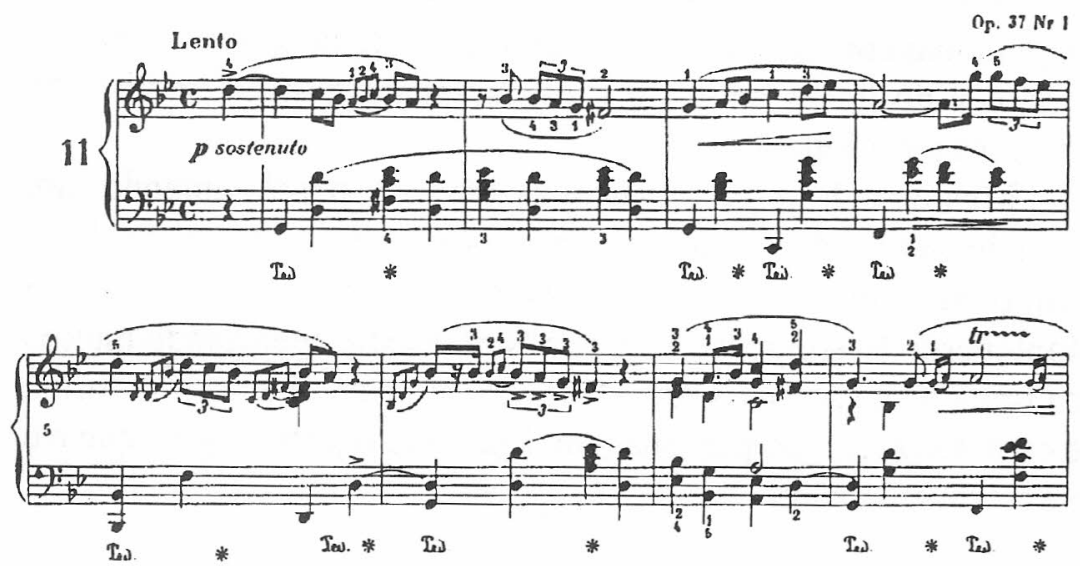

Sequenza para voz humana, de Luciano Berio; Pierrot Lunaire de Arnold Schönberg e, na música popular brasileira, o conjunto das canções do grupo Rumo.

\section{b) $O$ gesto musical integrado à representação teatral ou à narração de fatos ou enredos}

Sua principal característica é a de estar a serviço do enredo. Seja quando sublinha certos fatos importantes, seja quando toma para si o papel de participante do cenário ou quando toma para si o próprio papel de narrar ou representar, a música estará sempre, neste caso, condicionada pelos motivos do enredo, mais do que de seus próprios motivos. A ópera é o exemplo mais extremo, na medida em que assume integralmente a co-participação do teatro e da música na feitura do espetáculo.

A música programática pode estar tão vinculada a um enredo quanto uma ópera, sem que este seja explicitado em forma de texto literário. Mas é preciso que o programa seja um enredo e não um programa descritivo; caso contrário, estaria no campo já discutido do gesto descritivo. 


\section{c) $\mathbf{O}$ gesto musical integrado à representação de um papel teatral}

Aqui, a principal característica é ajudar à caracterização de um personagem. Talvez este campo faça parte do gesto dramático ou talvez do gesto inflexional, ou talvez do gesto descritivo de situações psicológicas.

Mas quando o personagem assume seu papel cantando, um exemplo salta sobre todos e torna obrigatória a separação deste campo de todos os outros: O Lamento da Ninfa de Claudio Monteverdi. E isto porque o que a Ninfa canta, agenciando muitos dos tipos de gestos músicais elencados até aqui, é a própria forma de caracterização do personagem. Ela canta o personagem que é e se descreve: lamenta.

\subsection{O uso gestual do silêncio}

Uma vez colocado o problema do gestual na música, o momento a seguir será o de localizar se o SILÊNCIO se encaixa e como se encaixa no mesmo.

\section{A) O silêncio como gesto musical sobre referência musical}

a) Metalingüísticos. Na variação XIII das Variações Diabelli op. 120, Beethoven coloca a nu a pobreza do tema de Diabelli ao manter apenas o esqueleto harmônico do tema e o pulso da valsa (3-1). Tudo o mais é suprimido como supérfluo, sendo substituído por silêncios. Silêncios que comentam este supérfluo. Silêncios metalingüísticos.

(Ver exemplo 19).

b) Conceituais. A obra 4'e 33" de John Cage, já citada, cobre este campo com clareza. Mas todo o silêncio que o chamado Teatro Musical imprime a suas obras, deixando que apenas o Gesto (latu sensu) do intérprete sugira um ritmo, um tempo musical, reminiscências, é também um claro exemplo do silêncio enquanto 
Exemplo 19 - Ludwig van Beethoven - Variações Diabelli op. $120-$ Ed. Peters n ${ }^{\circ} 4476$.
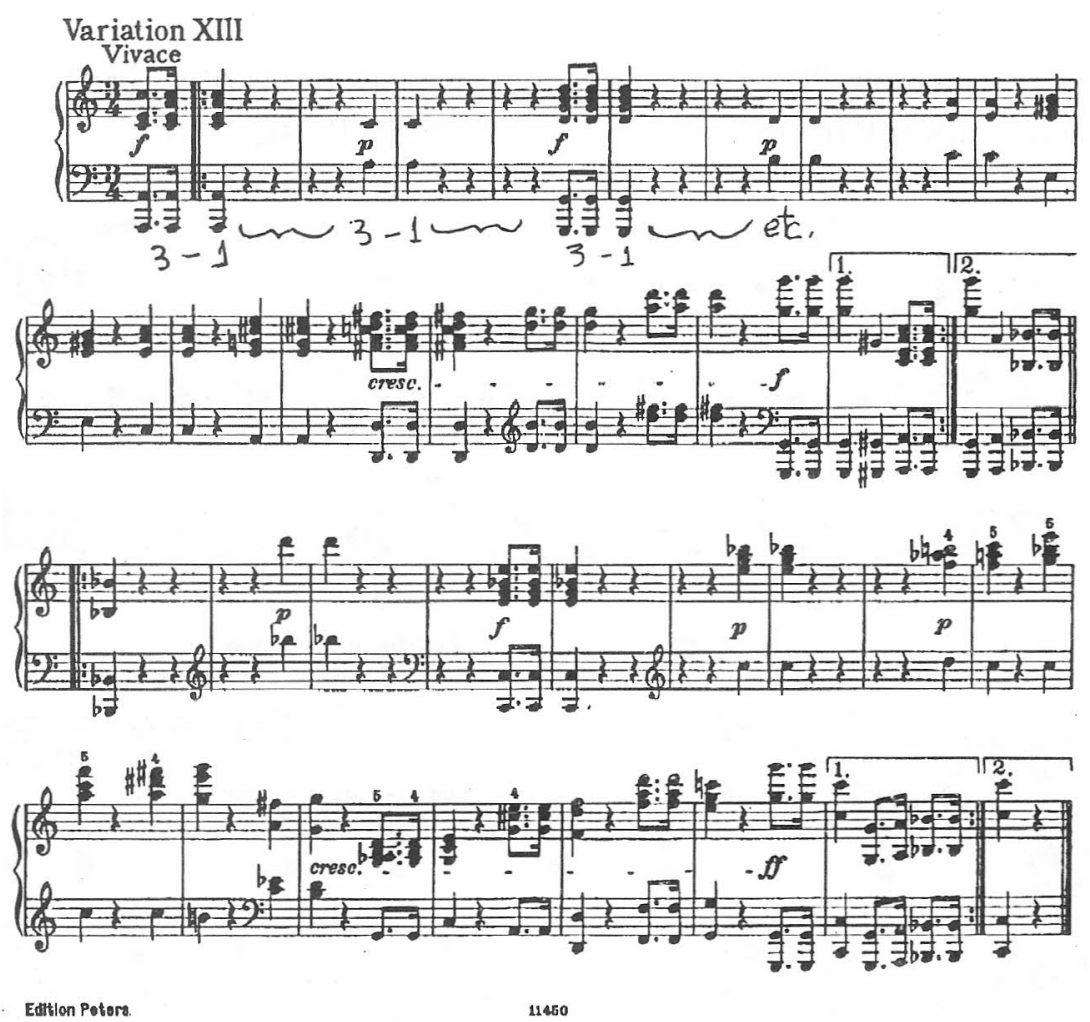

Conceito, como a obra Pausa e Menopausa de Gilberto Mendes, que alterna pequenos momentos de gente mexendo café em xícaras vazias (som) com uma enorme profusão de gestos faciais (silêncios).

\section{B) $O$ silêncio como gesto musical sobre referências não-musicais}

a) $\mathrm{O}$ silêncio como gesto musical descritivo

a.1) de situações psicológicas: o exemplo é de G. Puccini, Storiella d'Amore, compassos 35 a 36, e sugere um momento de arrebatamento, seja com a história contada no livro que está sendo 
lido pelos protagonistas da canção, seja com a história dos próprios protagonistas. Um pouco de emoção, um pouco uma sensação física de arrebatamento.

Exemplo 20 - Giaccomo Puccini - "Storiella d'Amore". In: The Unknown Puccini. Oxford University Press, 1987.
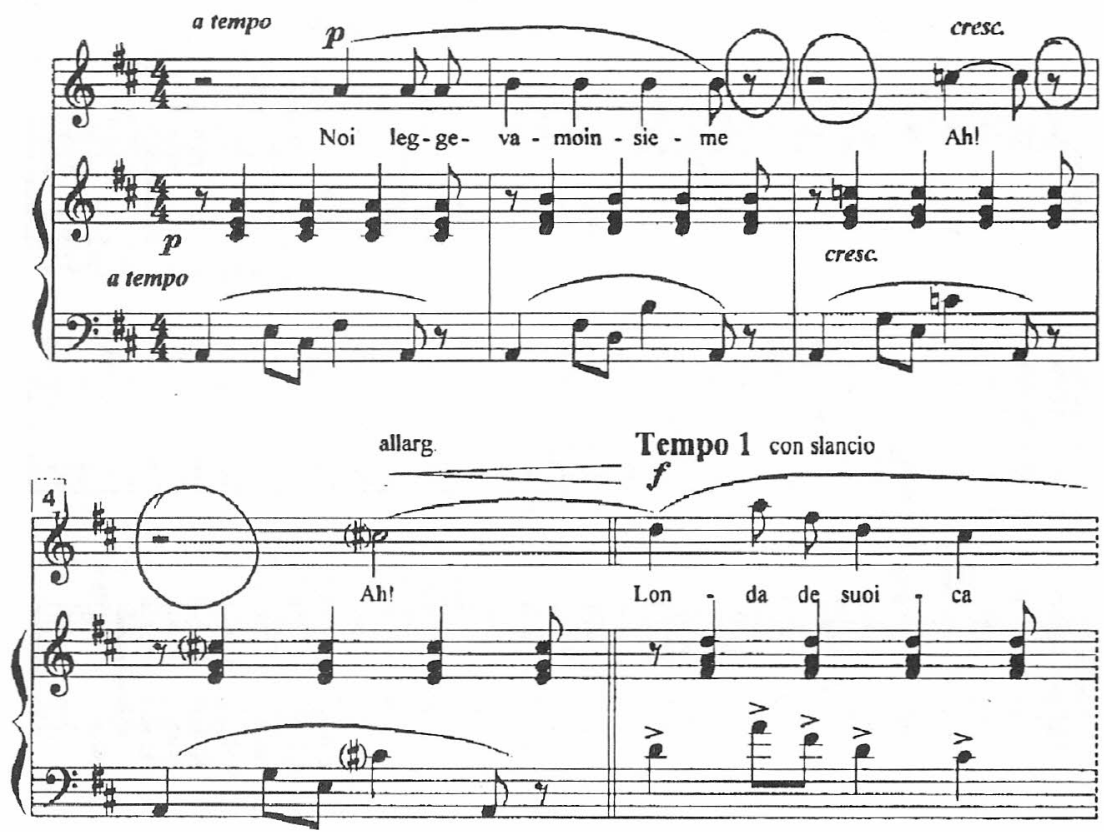

a.2) de situações visuais: $\dot{E}$ questa vita un lampo, de C. Monteverdi. Esta vida é um relâmpago (pausa) que ao aparecer, desaparece (pausa). Somado aos ziguezagues que as vozes fazem quando cantam o texto, o início deste madrigal publicado no livro Selva Morale e Spirituale usa o silêncio para afirmar a imagem visual de um relâmpago, que desaparece rapidamente.

(Ver exemplo 21).

a.3) miméticos: aqui temos ao menos três grandes exemplos: no madrigal de John Willie Alas, what hope of speeding (Ver exemplo 22), 
Exemplo 21 - Claudio Monteverdi - "É Questa Vita un Lampo". In: Selva Morale e Spirituale. Universal Ed., F. Malipiero, editor, Opere di Monteverdi, tomo XV/1.

$\grave{E}$ questa vita un lampo
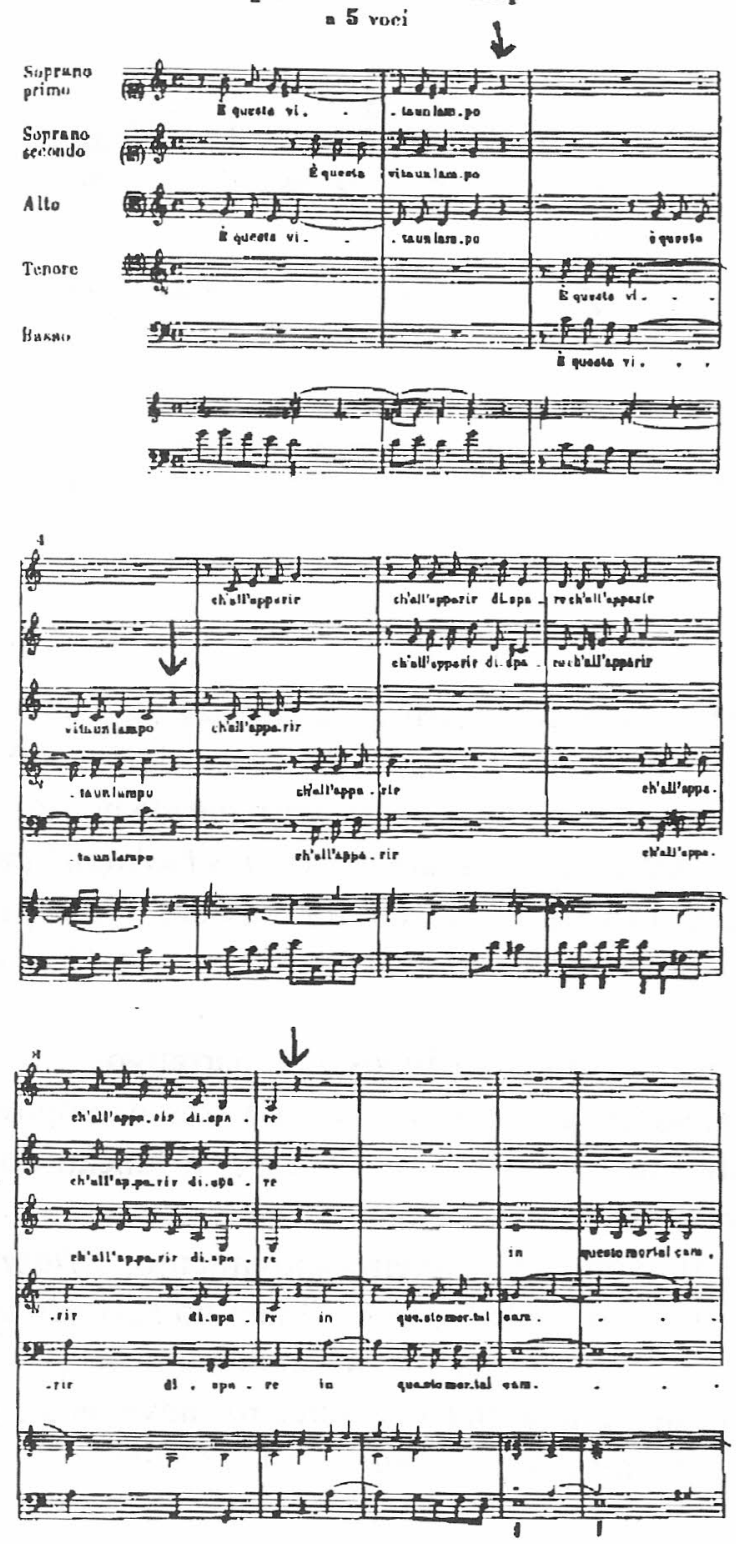
Exemplo 22 - John Wilbye - "Alas, what hope of speeding" - Cópia Manuscrita.

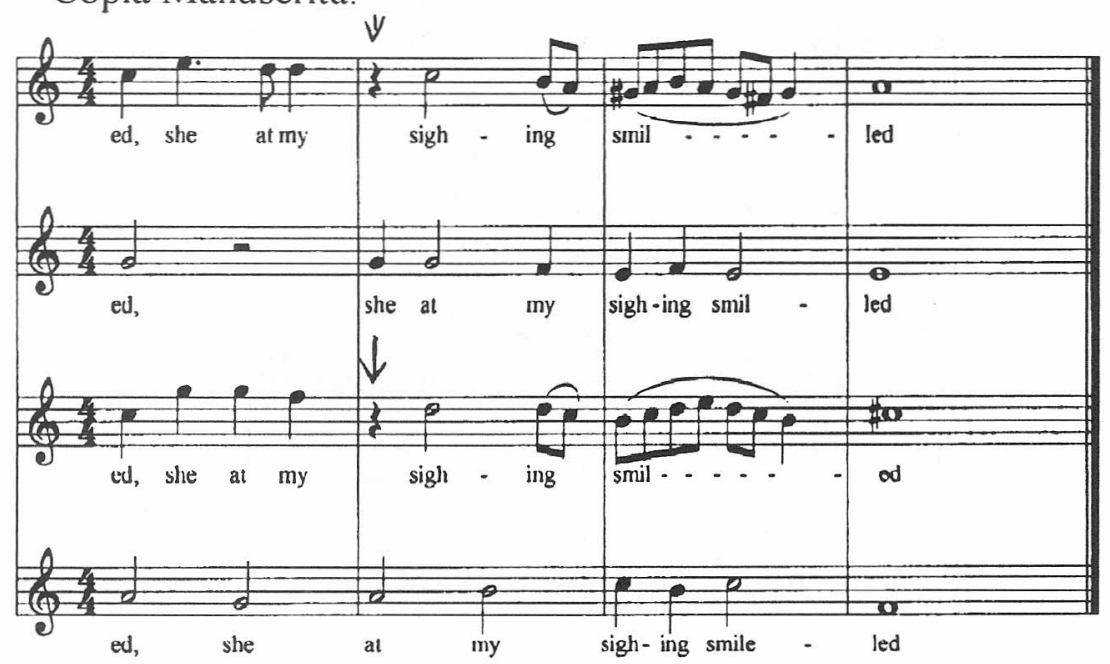

a melodia, fluente, do soprano se interrompe, preenchendo a palavra sighing, assim como no madrigal Piango, che amor de Luca Marenzio a palavra sospiro aparece duas vezes, entremeada por um silêncio; outro exemplo antológico é o dos hocchetus (soluços) medievais, presentes em tantos motetes da época, mas presentes inigualavelmente na Missa de Nôtre-Dame de Guillaume de Mauchaut.

b) Gestos musicais dramáticos e/ou narrativos

b.1) Inflexionais - Observando os três exemplos abaixo citados, verificamos o quanto, neste caso, a função do silêncio depende do contexto em que aparece.

Em Beethoven, no primeiro movimento, Allegretto, do Quarteto op. 135, as pausas que se situam no segundo tempo do segundo e quarto compassos parecem anunciar o caráter interrogativo que se fará claro no terceiro movimento, na chave léxica que o precede: Muss es sein? Es muss sein!

(Ver exemplo 25). 
Também se observarmos o Noturno $\mathrm{n}^{\circ} 13$ (op. $48 \mathrm{n}^{\circ} 1$ ) de F. Chopin, vamos sentir claramente inflexões de fala que dominam a melodia da mão direita (Ver exemplo 26), na parte A, fortemente sublinhadas, nessa caracterização, pelas pausas.

Exemplo 23 - Luca Marenzio - "Piango, che amor". In: Collana di composizione sacre e profane. Vol. III. Milano, Ed. Curci - Achile Schinelli, editor.

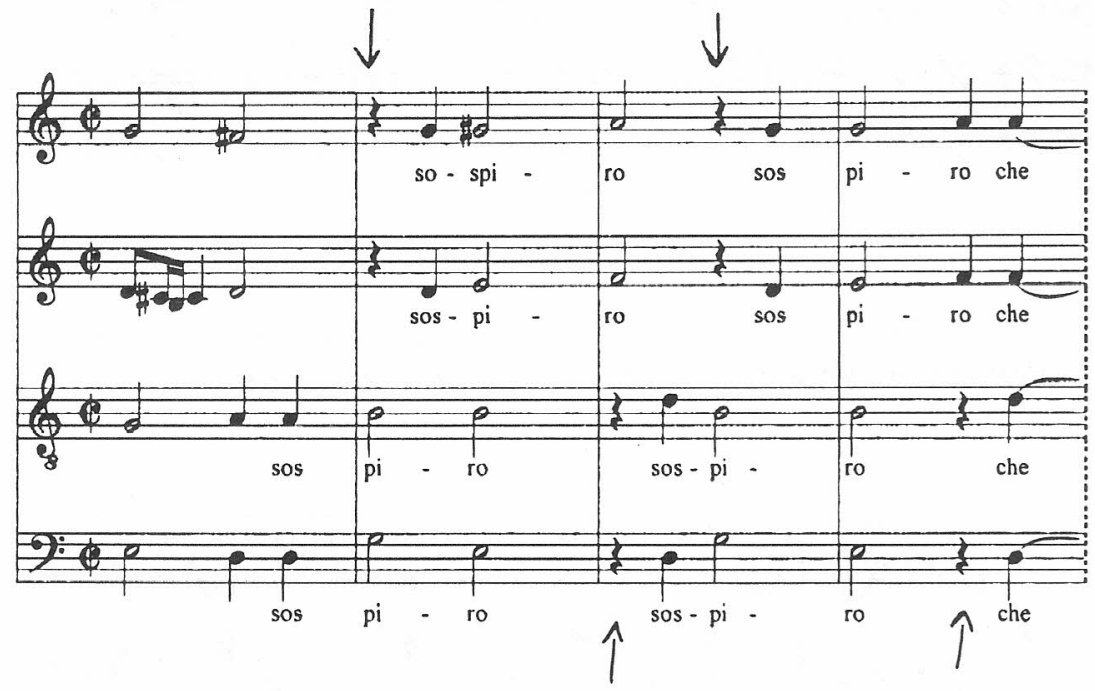

Exemplo 24 - Ludwig van Beethoven - Quarteto op. 135, em Fá Maior - Kalmus Study Scores n 762 .

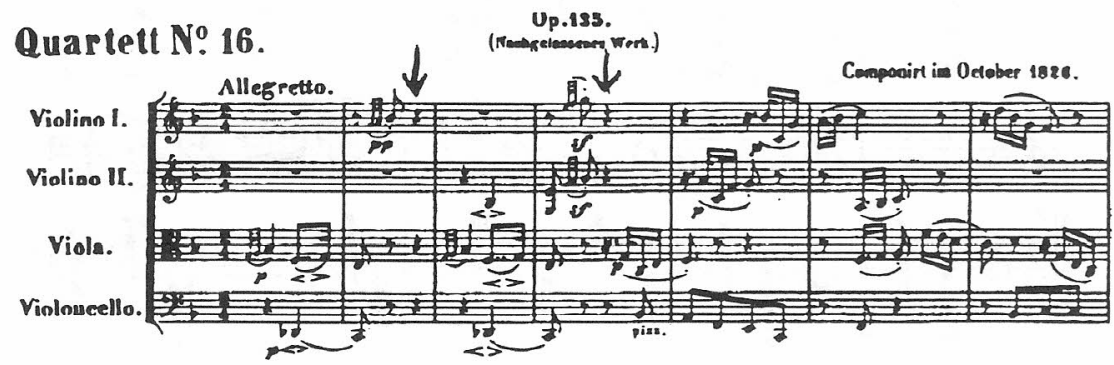


Exemplo 25 - Ludwig van Beethoven - Quarteto op. 135, em Fá Maior - Kalmus Study Scores n 762 .

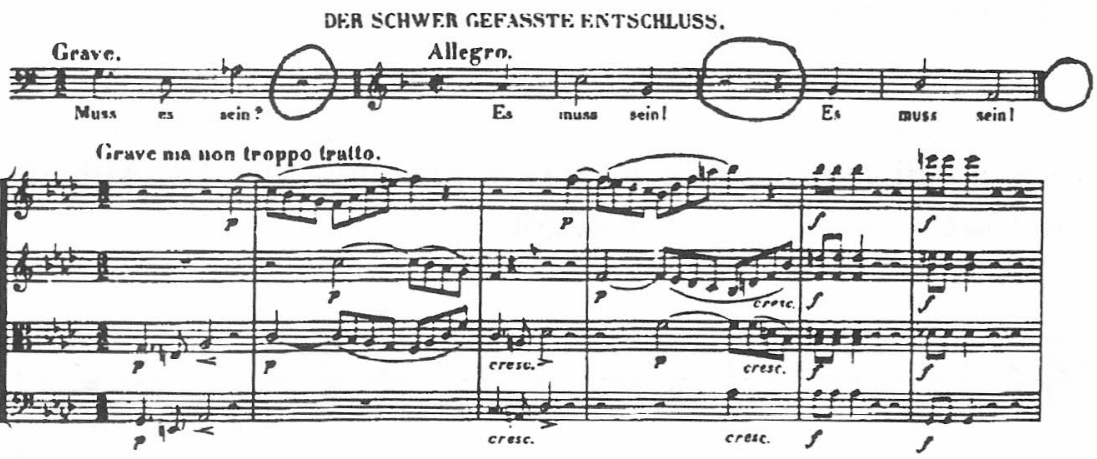

Exemplo 26 - Frédéric Chopin - Noturno op. 48 n 1. Polskie Widawnictwo Muziczne nº 238 - Paderewski, editor.

(1). 45 NP
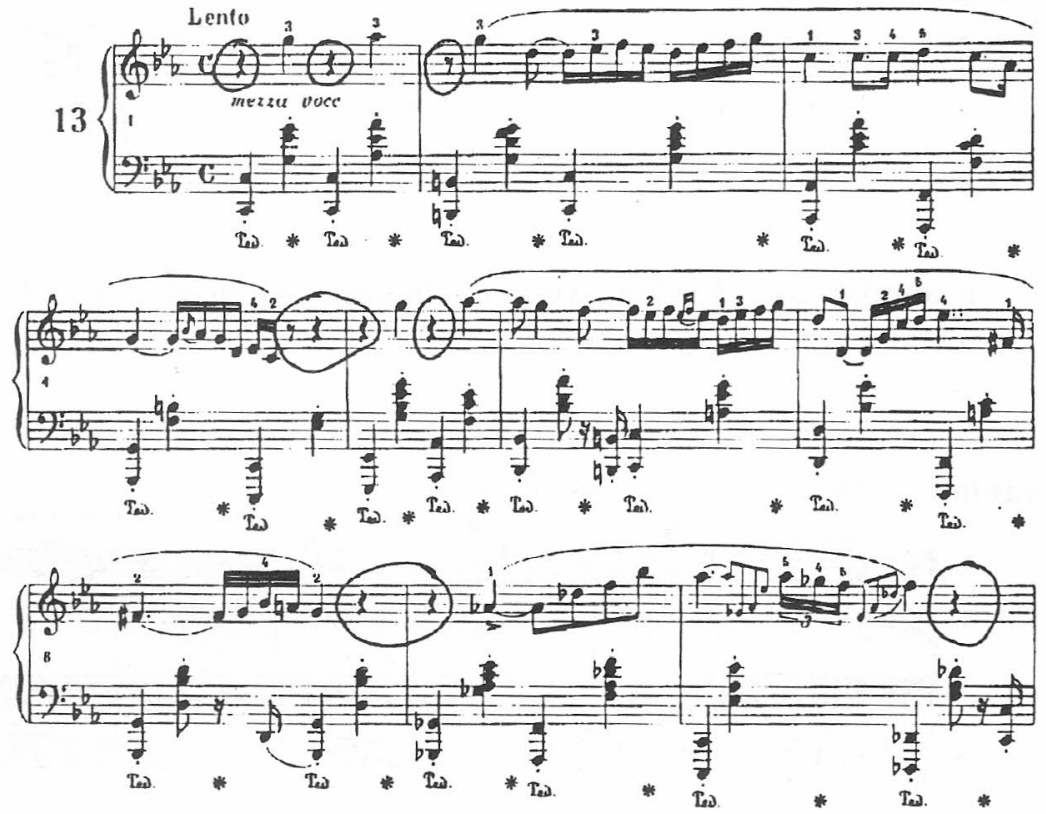
b.2) Integrados à representação teatral ou à narração de fatos ou enredos - Em Il Combattimento di Tancredi e Clorinda, a partir do compasso 58, os instrumentos imitam o avanço de cavalos; e as pausas, as paradas de espera. Daí em diante, o narrador ocupa este espaço de silêncio dos instrumentos, mas, a partir do compasso 72 , ele se cala, e o discurso narrativo é retomado a partir dos instrumentos e seus silêncios até o compasso 87.

b.3) Integrados à representação de um papel teatral Retomamos o exemplo empregado quando falávamos deste campo, referindo-nos à música em geral e não apenas aos silêncios. $O$ Lamento da Ninfa, de Monteverdi. Ali o personagem emprega o silêncio como algo que ajuda a caracterizar o seu papel. As freqüentes interrupções de seu discurso ajudam à caracterização de um "Lamento", silêncios que, pontualmente, até possuem claramente outras funções - como poderá mostrar uma análise mais apurada - mas que no seu conjunto trabalham a favor do perfil do personagem.

Não pretendemos, neste artigo, estabelecer uma taxionomia ou uma teoria dos usos do silêncio. Após estas reflexões, nascidas do contato com o trabalho composicional e analítico, concluímos que o uso do silêncio está estreitamente relacionado às suas margens. Para além das funções do silêncio na música, há uma característica possível de ser encontrada em qualquer silêncio (especialmente se total): ele pode ser atrativo ou repulsivo em relação às suas margens. Aqueles que repelem suas margens parecem estar reservados à ação da memória, com uma característica quase atemporal. Aqueles que atraem as margens parecem estar reservados à expectativa, ao domínio geral da ação, da próxima informação. Através da análise da função que determinado silêncio ocupa no discurso musical, pode-se chegar ao domínio da expectativa, da calma, da memória, da ansiedade, tornando o não-som um dado tão importante como qualquer outro na criação, na interpretação e, consequentemente, na educação musicais. 


\section{NOTAS}

1. Neste texto, não estamos considerando as implicações físicas, psicológicas ou filosóficas do assunto. Trata-se de um estudo restrito ao uso musical do silêncio e às necessidades de uma melhor compreensão destes usos objetivando a composição e a análise musicais.

2. Utilizamos o conceito de "liquidação" como a maneira de propiciar uma finalização preliminar de uma seção e assim permitir o aparecimento de uma outra idéia musical, tal como definido por A. Schöenberg em seu artigo "Connection of Musical Ideas" in Style and Idea, p. 287-288.

3. Sobre o uso da função metalingüistica na linguagem ver o artigo de $R$. Jakobson, "Lingüística e Poética", in: Lingüistica e Comunicação, p. 127130.

4. Claudio Monteverdi - Lettere, Dediche e Prefazione, p. 416-418.

5. Uma análise detalhada desta obra pode ser vista em nossa dissertação de mestrado, Canto Coral: do repertório temático à construção do programa.

\section{BIBLIOGRAFIA}

CHAILLEY, Jacques. Introduction à Messe Notre-Dame . Paris, Ed. Salabert, 1948.

JAKOBSON, R. "Lingüística e Poética". In: Lingüistica e Comunicação.

MONTEVERDI, Claudio. Lettere, Dediche e Prefazione. Roma, Edizioni de Santis, 1973.

RAMOS, Marco Antonio da Silva. Canto Coral: Do Repertório Temático à Construção do Programa. Dissertação de Mestrado. São Paulo, ECAUSP.

SCHAEFFER, Pierre. La Musique Concrète. Paris, Presses Universitaires de France, 1967.

SCHÖNBERG, Arnold. Style and Idea. New York, St. Martin Press, s/d.

\section{ÍNDICE DE OBRAS CITADAS}

ADAM de la Halle - Or est Bayard, Rondeaux para coro a 3 vozes iguais.

BACH, Johann Sebastian - Toccata e Fuga em ré menor BWV 565, para órgão.

BANCHIERI, Adriano - Ad un dolce usingolo, madrigal a 5 vozes mistas.

BARTÓK, Béla - Mikrokosmos - vol. VI para piano.

BEETHOVEN, Ludwig van - Quinta Sinfonia - op. 67 - Dó menor. Nona Sinfonia - op. 125 - Ré menor. Quarteto de Cordas - op. $133 \mathrm{~cm}$ si bemol maior. Quarteto de cordas op. 135 em Fá Maior. Variações Diabelli, op. 120, para piano. 
BERIO, Luciano - Sinfonia. Sequenza para voz humana.

BRAHMS, Johannes - Liebeslieder Walzer op. 52 para piano a 4 mãos e coro ad libitum.

CAGE, John - 4'33"

CHOPIN, Frédéric F. - Ballade, op. $52 \mathrm{n}^{\circ} 4$ para piano. Noturno $\mathrm{n}^{\circ} 11$, op. 37 $\mathrm{n}^{\circ} 1$ para piano. Noturno $\mathrm{n}^{\circ} 13$, op. $48 \mathrm{n}^{\circ} 1$ para piano.

FAURÉ, Gabriel - Cantique de Jean Racine op. 11 para coro misto e piano (ou órgão).

GARCIMUÑOZ - Una montaña pasando, para coro a 4 vozes, do Cancioneiro Musical de Palacio vol. 1.

GESUALDO DI VENOSA, Carlo - Moro, lasso, al mio duolo, para coro misto a 5 vozes, do $6^{\circ}$ Livro de Madrigais.

HAYDN, Joseph - Sinfonia em Sol "Militar"- Hoboken I:100.

JANEQUIM, Clément - La Bataille de Marignan (La Guerre), para coro misto a 4 vozes. Le chant des oiseaux, para coro misto a 4 vozes. Le chant de l'allouette, para coro misto a 4 vozes. Les cris de Paris, para coro misto a 4 vozes. Le caquet des fenmes, para coro misto a 4 vozes.

JOSQUIN des Près - El grillo è buon cantore para coro misto a 4 vozes.

LICHFILD, Henry - Injurious Hours para coro misto a 5 vozes.

LISZT, Franz - Christus ist geboren, para 3 vozes femininas. A Batalha dos Hunos, poema sinfônico.

MAHLER, Gustav - Segunda Sinfonia, em Dó menor, Quinta Sinfonia, em Dó bemol menor.

MAUCHAUT, Guillaume de - Missa Nôtre-Dame para 4 vozes masculinas

MARENZIO, Luca - Piango, che amor para coro misto a 4 vozes.

MENDELSSOHN- BARTHODDY, Felix - Auf dem See op. $41 n^{\circ} 6$ para coro misto a 4 vozes.

MENDES, Gilberto - Pausa e menopausa para 3 intérpretes, xícaras de café, projeção de slides, ação teatral.

MESSIAEN, Olivier - Modes de valeur et d'intensité.

MONTEVERDI, Claudio - Ecco mormorar l'onde, para coro misto a 5 vozes do $2^{\circ}$ livro de Madrigais. A un giro sol de 'bell' occhi lucenti, para coro misto a 5 vozes do IV Livro de Madrigais. Combattimento de Tancredi et Clorinda, rappresentativo do $8^{\circ}$ Livro de Madrigais, $1^{\text {a }}$ parte - Cantos Guerreiros. Lamento della Ninfa rappresentativo do $8^{\circ}$ Livro de Madrigais, $2^{\mathrm{a}}$ parte - Canti amorosi. E questa vita un lampo para coro misto a 5 vozes da Selva Morale e Spirituale.

MOZART, W. A. - Recitativo da Rainha da Noite em: A Flauta Mágica K 620. PUCCINI, G. Storiella d'Amore, in: The unknown Puccini.

RAMOS, Marco Antonio da Silva - Três Historietas del Viento para coro misto e clarinete.

RAVEL, Maurice - Bolero. 
SATIE, Erik - Três peças em forma de pera, para piano a 4 mãos.

SCHOENBERG, Arnold - Pierrot Lunaire, op. 21.

STRAWINSKY, Igor - A Sagração da Primavera.

TCHAIKOVSKY, P. I. - Abertura 1812.

WEBERN, Anton - 5 Peças para orquestra op. 10.

WILBYE, John - Alas, what hope of speeding para coro misto a 4 vozes.

Marco Antonio da Silva Ramos é regente coral e professor do Departamento de Música da ECA-USP. 